\title{
ESG Disclosure, REIT Debt Financing and Firm Value
}

\author{
Zifeng Feng ${ }^{1} \cdot$ Zhonghua $\mathrm{Wu}^{2}$
}

Accepted: 14 July 2021

(c) The Author(s), under exclusive licence to Springer Science+Business Media, LLC, part of Springer Nature 2021

\begin{abstract}
Using recently available GRESB ESG public disclosure data for REITs around the world, we examine how ESG disclosure is related to REIT debt financing and firm value. We find that REITs with higher levels of ESG disclosure have lower cost of debt, higher credit ratings, and higher unsecured debt to total debt ratio, controlling for key firm characteristics. These findings suggest that improving ESG disclosure can help REITs to gain better access to the capital markets and enhance corporate financial flexibility, as lenders have paid close attention to a firm's ESG disclosure and integrated evaluation of ESG factors into their lending decisions. Moreover, firm value of REITs is positively associated with their ESG disclosure level. When using the Covid-19 pandemic as a quasi-experimental setting, we find evidence that REITs with higher ESG disclosure levels before the pandemic exhibit higher firm value during the pandemic. These results indicate that investors do value active ESG disclosure by REITs. Additional analyses show that ESG disclosure level is sensitive to institutional ownership, implying that institutional investors may drive REIT ESG disclosure efforts. Taken together, this paper suggests that effective ESG disclosure can have a positive impact on REIT debt financing and firm value due to the increased corporate transparency, and the ESG reporting framework developed by GRESB appears to be effective to provide transparency and comparability across the global real estate industry.
\end{abstract}

Keywords ESG disclosure · Debt financing · Financial flexibility · Firm value

Zhonghua Wu

wuz@fiu.edu

Zifeng Feng

zfeng@utep.edu

1 Department of Economics and Finance, The University of Texas At El Paso, $500 \mathrm{~W}$. University Ave, El Paso, TX 79968, USA

2 Hollo School of Real Estate, Florida International University, 1101 Brickell Ave, Miami, FL 33131, USA 


\section{Introduction}

Around the globe, investors, lenders and other stakeholders have been increasingly integrating Environmental, Social, and Governance (ESG) factors into their business decisions in recent years ${ }^{1}$. To incorporate the ESG issues in their decision-making, stakeholders must be able to accurately capture ESG related information disclosed by firms. However, recent research suggests that ESG criteria are hard to define and there is substantial disagreement across ESG data providers on what ESG rating to give to individual firms (e.g., Christensen et al., 2021). Without the consistency and transparency from an effective, standardized ESG disclosure framework, investors and lenders might be misled by various ESG ratings and face significant risks when making investment or lending decisions. Thus, it is not surprising that ESG disclosure has received significant attention recently.

For REITs, ESG disclosure has become a critical issue for their investors, lenders, as well as the industry associations in recent years ${ }^{2}$. According to a REIT industry ESG report by the National Association of Real Estate Investment Trusts (Nareit) in 2020, there is a growing demand from investors and lenders for REITs to disclose ESG related information ${ }^{3}$.To facilitate REITs to proactively disclose ESG information anticipated by various ESG reporting frameworks, Nareit recently offered the first guide to help its members to understand and navigate the array of ESG disclosure frameworks. Also, in 2019 the European Public Real Estate Association (EPRA) launched a comprehensive database covering publicly available ESG data from European REITs in an effort to promote ESG disclosure by the firms.

With the growing demand for ESG disclosure from REIT stakeholders and the new set of non-financial reporting guidelines related to ESG factors, it is important for REITs to manage their ESG disclosure as they are monitored and benchmarked by ESG rating companies relative to their peers. ${ }^{4}$ Greater transparency resulting from active ESG disclosure can lead to more scrutiny of REITs' operating models, carbon footprints and exposure to climate change, which can drive the firms to reexamine their business practices and integrate ESG criteria into their operations and

\footnotetext{
${ }^{1}$ E.g., according to a report by the Forum for Sustainable and Responsible Investment (USSIF), total US-domiciled assets under management using ESG strategies experienced a $42 \%$ increase from 2017 to 2019. This represents about $33 \%$ of the US assets under professional management. More details can be found at the following website: https://www.ussif.org/files/Trends/2020_Trends_Highlights_OnePager. pdf. Also, banks around the world are required to incorporate ESG risks in their lending decisions. See a report titled "Lenders must set clear ESG targets under new UN responsible banking framework" by S\&P Global Market Intelligence on October 8, 2019.

${ }^{2}$ Like US REITs, REITs in other regions face growing pressure to improve ESG disclosures. E.g., for European REITs, please see the following website: https://www.reit.com/news/videos/european-reitsshowing-increased-focus-social-and-governance-reporting; for Japanese REITs, please see: https://gresb. com/nikkei-inc-launches-a-green-reit-index/.

3 Based on the report, over two-thirds of Nareit members indicate that the demand by their stakeholders such as investors and lenders for ESG disclosure has continued to increase over the past year.

${ }^{4}$ E.g., Equinix Inc. has established its data disclosure practices and developed customized templates to help its customers to monitor their energy and carbon data. Equinix believes that the transparency can ultimately drives ESG improvement, and their approach for ESG disclosure provides greater transparency and serves as a key differentiator for the company relative to its peers.
} 
investment decisions. Hence, one would expect that the growing demand for ESG disclosure and the new reporting requirements profoundly influence REIT operations and performance.

Despite the importance of ESG disclosure to REITs around the world, research about how it influences REITs has been limited. To a large extent, the limited research on this topic is due to a lack of data on REIT ESG disclosure, which is not available until recently ${ }^{5}$. Meanwhile, most of the existing studies on REIT ESG issues focus on the effects of ESG performance. For instance, using LEED and Energy Star building data to measure environmental performance, Eichholtz et al. (2019) investigate the impacts of ESG performance on cost of capital of REITs. Given the significance of ESG disclosure to REITs and limited research in this area, we empirically examine how ESG disclosure is related to REIT debt financing and firm value, using newly available ESG disclosure data provided by Global Real Estate Sustainability Benchmark (GRESB) for REITs around the world.

It is worth noting that there exist substantial differences between ESG disclosure and ESG performance data for REITs. According to GRESB, ESG disclosure data evaluate what and how effectively ESG-related information is disclosed by REITs (from "GRESB Public Disclosure" database). The ESG performance data (from "GRESB Real Estate Assessment" database), however, assess a REIT's ESG policies and activities based on a set of performance indicators, i.e., how well a REIT performs based on various ESG criteria. In other words, the disclosure data reflect the level of effectiveness or transparency in reporting ESG-related information, while the performance data evaluate the performance against a set of REIT ESG factors. The focus of our study is on how ESG disclosure is related to REIT debt financing and firm value.

There are several reasons why it is interesting to examine the relations between ESG disclosure and REIT debt financing and firm value. Previous literature based on non-REIT firms presents mixed results on the relations. Some studies find evidence that firms experience negative abnormal returns or have lower likelihood to issue external financing when they disclose more ESG related information (e.g., Christensen et al., 2021; Jacobs et al., 2010). Others document a positive relationship between ESG (or CSR) disclosure and firm performance or financing activities (e.g., Dhaliwal et al., 2011; Plumlee et al., 2015). However, the relations can be different for REITs.

First, real estate is a capital extensive industry and many REITs around the world are required to pay a large portion of their earnings as dividends (see Dogan et al., $2019)^{6}$. As a result, unlike non-REIT firms, REITs hold little cash and must heavily depend on external capital markets to fund their investment and growth (Ott et al., 2005). Thus, it is important for REITs to gain good access to the capital markets

\footnotetext{
${ }^{5}$ In 2019, Global Real Estate Sustainability Benchmark (GERSB) started to provide global REIT ESG disclosure data.

${ }^{6}$ Dogan et al. (2019) show, while REIT dividend payout rules vary across different countries, many REITs in different countries distribute a large portion of earnings as dividends. These countries include Belgium, France, Hong Kong, Japan, Netherlands, Singapore, South Africa, UK, and US.
} 
and lower the cost of debt in order to stay competitive. Also, as REITs are typically highly leveraged (Giacomini et al., 2017; Letdin et al., 2019), retaining financial flexibility (i.e., a firm's ability to address future liquidity shocks in a timely and costefficient manner) is critical for REITs due to their institutional idiosyncrasies (Riddiough \& Steiner, 2020). Given the growing demand from lenders on ESG information and REITs are more capital market dependent, ESG disclosure can improve corporate transparency and facilitate REITs to access the capital markets. Therefore, a study based on REIT data (from a single, relatively homogeneous industry) may provide a better understanding on the relations between ESG disclosure and firm financing, and thus add to the broader literature.

Second, ESG disclosure can help REITs to mitigate information asymmetry and thus have a positive impact on firm value. Information asymmetry is an interesting issue for REITs. Many believe REITs are relatively transparent as they hold a portfolio of tangible assets with substantial property level information. Others argue that information asymmetry still exists between REITs and their investors, as it is difficult to estimate the fair market value of real property transactions that include a wide range of heterogeneous, illiquid assets (Feng et al., 2007). Also, REITs are often involved in new development and may have joint venture liabilities that are not fully disclosed, which makes some firms less transparent than their peers. Thus, arguably the information asymmetry problems are still relevant to REITs. Moreover, extant studies show that information asymmetry can be temporal for REITs (Devos et al., 2019) and greater transparency facilitates REIT firm growth (An et al., 2011). Hence, it is interesting to examine how ESG disclosure is related to firm value of REITs given the information asymmetry issues of REITs.

Finally, the demand and requirements for ESG disclosure are relatively new to REITs around the world. As indicated in the ESG Reporting Guide published by Nareit in $2019^{7}$, there are twelve (12) different reporting frameworks or guidelines for REITs to disclose their ESG information, and many REITs have struggled to identify which ESG factors or reporting frameworks are more relevant to them in order to effectively disclose ESG information. Thus, it is meaningful to study the relations between ESG disclosure and REIT debt financing and firm value, using the ESG disclosure data provided by GRESB, which is considered as the leading ESG data provider for real estate firms. The findings from such a study can shed light on whether GRESB ESG reporting system is effective for the global real estate industry and help REITs and their stakeholders to efficiently manage their ESG reporting or make sound business decisions.

To sum up, ultimately it is an empirical question of how ESG disclosure is related to REIT debt financing and firm value as there is mixed evidence in the nonREIT literature. Also, while one can argue that effective ESG disclose should help REITs to gain better access to the capital markets and have a positive impact on firm value due to increased transparency with investors and lenders, it is costly for

\footnotetext{
7 See the guiding report at: https:/www.reit.com/sites/default/files/media/PDFs/Research/Nareit_Guide_ to $\%$

20ESG_Reporting_2_21_19.pdf.
} 
firms to disclose ESG information and comply with environmental and sustainability regulations. ${ }^{8}$

To conduct the empirical analysis, we use a newly available GRESB ESG disclosure dataset for REITs in different global regions. Our emphasis is on how ESG disclosure is related to the firm-level cost of debt, financial flexibility and firm value of REITs. Given that the movement for promoting ESG practices is truly a global phenomenon (Dyck et al., 2019), we use the global data to examine REIT ESG disclosure level in the different regions and study the effects of ESG disclosure for REITs around the world.

We first provide some descriptive evidence on ESG disclosure level of REITs. Based on our sample, the ESG disclosure level is largely distributed evenly across different property types and global regions. The average ESG disclosure level is 3.12 (out of 5). Regarding property type, the healthcare REITs have the highest average disclosure level (4.1) while the office REITs have the lowest level (2.1). As for geographic region, REITs from North America exhibit the highest average disclosure level (3.4) and the Asian-Pacific REITs have the lowest disclosure level (2.1). Not surprisingly, REITs continue to improve their ESG disclosure during COVID-19 crisis. The average disclosure level of REITs increases from 3.08 (2019) to 3.35 (2020).

Next, we examine how ESG disclosure level is associated with the cost of debt and financial flexibility of REITs, controlling for key firm characteristics such as financial performance, firm size and leverage. We find that there is a strong, negative relation between ESG disclosure level and the cost of debt of REITs (measured by interest to debt ratio and weighted average interest rate). Also, REITs with higher ESG disclosure levels have greater financial flexibility (measured as non-secured debt to total debt ratio) and higher corporate credit ratings ${ }^{9}$. These findings suggest that it is important for REIT to proactively disclose ESG information and that improving ESG disclosure may help them to gain better access to the capital markets and enhance corporate financial flexibility, as lenders have paid close attention to a firm's ESG disclosure and increasingly integrated evaluation of ESG factors into their lending decisions ${ }^{10}$.

Moreover, we find that REITs disclosing more ESG information have higher firm value. When the Covid-19 pandemic is used as a quasi-experimental setting, we find evidence that REITs with higher ESG disclosure levels before the pandemic have relatively higher firm value during the pandemic, when the pandemic prompted a sharp fall in REIT stock market. These results indicate that investors do value proactive ESG disclosure by REITs, as it reduces information asymmetry and increases corporate transparency. Consistent with the finance literature, we also document that REITs with higher institutional ownership have higher ESG disclosure levels,

\footnotetext{
${ }^{8}$ Many argue that ESG disclosure often involves direct costs of information production and due diligence, and indirect liabilities of information auditing and monitoring by stakeholders such as activists and governments.

${ }^{9}$ Previous literature (e.g., Kisgen, 2006; Qian and Strahan, 2007) shows that corporate credit ratings heavily influence a firm's cost of borrowing.

${ }^{10}$ In other words, lenders embrace active ESG disclosure as it represents a REIT's efforts and commitments to promote corporate transparency.
} 
suggesting that institutional investors may drive REIT ESG disclosure efforts ${ }^{11}$. We argue the latter finding provides indirect evidence on the impacts of ESG disclosure on REIT debt financing and firm value as institutional investors likely serve as an effective monitor or activist on ESG disclosure issues.

To provide additional supporting evidence on the relations, we conduct a range of robustness checks. A propensity score matching model is used to address the potential omitted variable problem. The results are highly consistent. We also show that there exist substantial differences in REIT debt financing and firm value for REITs with and without ESG disclosure ratings in the sample. REITs disclosing ESG information tend to have the lower cost of debt, greater financial flexibility and higher firm value relative to those without the ESG ratings.

Taken together, our study suggests that active ESG disclosure can have a positive impact on REIT debt financing and firm value. Thus, it is imperative for REITs to consider the strategic consequences from climate changes, social responsibility and other ESG factors and effectively manage their ESG disclosure. A lack of an efficient ESG reporting process can place a REIT at a significant disadvantage in the capital markets, e.g., more difficult to gain access to the capital markets and have lower stock valuation due to increased risk profiles. Furthermore, as ESG disclosure for REITs are still at the early stage, our study suggests that the standardized ESG reporting framework provided by GRESB appears to be effective to provide transparency and comparability across the global real estate industry.

To our knowledge, this is the first study that examines ESG disclosure issues for global REITs, with a focus on the relations between ESG disclosure and REIT debt financing and firm value, using the newly available data by GRESB. Given the significance of ESG to REITs and the increasing demand from REIT stakeholders on ESG disclosure, this paper fills a gap in the literature by providing some initial evidence on ESG disclosure level for REITs around the world and studying how it is related to REIT debt financing and firm value. The results of the paper provide important implications for REIT managers and stakeholders.

Moreover, by using data from a relatively homogeneous industry, where firms heavily rely on external capital markets and ESG issues are highly relevant to both firms and their stakeholders, we provide consistent evidence on the relations between ESG disclosure and the cost of debt, financial flexibility, credit ratings and firm value. The results are likely more reliable than those studies based on firms across different industries as their samples have larger variations in capital structure, financing cost and ESG disclosure level. In this sense, this paper also adds to the broader finance literature.

The rest of the paper is organized as follows. Section 2 describes the background and literature related to REIT ESG disclosure. Section 3 discusses the data sources, variable construction, and summary statistics. Section 4 reports the research methods and empirical results. Section 5 provides the results from additional analysis. Section 6 concludes the paper.

11 Dyck et al. (2019) show that institutional investors drive corporate CSR performance. 


\section{Background, Literature and Hypothesis Development}

\section{The Importance of ESG on REITs}

Environmental, Social, and Governance (ESG) are of great importance to REITs due to the nature of real estate business, growing risks from climate changes, and the increasing demand for sustainability and social responsibility from REIT stakeholders in recent years. First of all, environmental issues have long been a focused area for REITs as commercial properties are one of the primary locations of energy consumption. According to a report by US Department of Energy in $2010^{12}$, residential and commercial buildings account for $40 \%$ of all energy used in the U.S., with two of the largest energy users being office and retail sectors. More recently, research shows that commercial real estate accounts for about $20 \%$ of the annual greenhouse gas emissions in the US ${ }^{13}$. Also, environmental risks associated with climate changes and natural disasters have recently received much attention by real estate investors (Cloutier, 2020). Given the importance of these environmental issues, many REITs have made significant investments in energy-saving technology and ecological building materials, as well as improved their environmental management practices.

Moreover, real estate is essentially a local business and business decisions made by REITs have direct impacts on the surrounding environment of their properties. Thus, it is important for REITs to pay close attention to social responsibility issues in order to perform well in the long term. In other words, as commercial properties provide spaces and environments for people to live, work, and enjoy (Chiang et al., 2019), they serve as one of the cornerstones for social and economic activities. Hence, it is not surprising that REITs have strived to increase their social engagements with tenants and employees on sustainability issues, with residents and customers in the local community for health and well-being in order to achieve sustainable businesses and stay competitive in the marketplace.

Furthermore, REITs have a long history to commit themselves to sound governance policies and practices. Commercial properties are one of the leading places that reflect interest alignments among owners, tenants, customers, and employees. Real estate firms must strengthen their accountability, transparency, ethics and integrity in their corporate governance. Indeed, according to a recent report by Nareit, many REITs have recently established cross-functional ESG teams, adopted ESG-related executive compensation policies, and aligned their governance goals with ESG criteria $^{14}$.

\footnotetext{
${ }^{12}$ See the report at: https://www1.eere.energy.gov/buildings/publications/pdfs/corporate/bt_stateindus try.pdf.

${ }^{13}$ See a report by Energy Star (2020). "Commercial Real Estate: An Overview of Energy Use and Energy Efficiency Opportunities". https://www.energystar.gov/sites/default/files/buildings/tools/Comme rcialRealEstate.pdf.

${ }^{14}$ For more details, see the report at: https://www.reit.com/investing/reits-sustainability/reits-and-gover nance.
} 
To summarize, because of the significance of ESG issues to the real estate industry, it is vital for REITs to integrate ESG issues into their business decisions (Hudson, 2019) ${ }^{15}$. Meanwhile, REIT stakeholders such as lenders and investors have been increasingly demanding sustainability and social responsibility for REITs. Thus, many argue that ESG has become a critical factor in the real estate business decision-making, not just an emerging trend (Cloutier, 2020).

\section{The ESG Literature on REITs and Non-REIT Firms}

There is an extensive literature on ESG issues for non-REIT firms and it has been growing in recent years (e.g., Pastor et al., 2021; Pedersen et al., 2021) ${ }^{16}$. Most of the ESG literature focuses on the causes and effects of ESG performance. For instance, one strand of the literature examines the cross-sectional differences in observed levels of ESG performance ratings and the wealth effects of ESG practices and policies, with a particular emphasis on the positive impacts provided by institutional investors (e.g., Azar et al., 2021; Dimson et al., 2015; Hoepner et al., 2021). Specifically, Dimson et al. (2015) analyze a proprietary database of ESG engagements with U.S. public firms and find that firms with socially conscious institutional investors and inferior governance are more likely to be engaged and that successful ESG engagements are followed by positive abnormal returns. After successful engagements, firms experience improved accounting performance and increased institutional ownership. Azar et al. (2021) study the role of the "Big Three" (i.e., BlackRock, Vanguard, and State Street Global Advisors) on the reduction of corporate carbon emissions. They document that the Big Three increase their engagement efforts on firms with high carbon emissions, and subsequently those firms reduce their carbon emissions.

Regarding the relation between debt financing and ESG concerns, the research is relatively limited and the evidence from the literature is inconclusive. For instance, Goss and Roberts (2011) find that firms with greater ESG concerns pay higher interest rates on their banks loans. Zerbib (2019) show that green bonds to fund environmentally friendly projects tend to have lower cost of debt. However, Flammer (2021) finds that yield spreads between a firm's green bonds and its other bonds are not significantly different, implying that the cost of debt is not lower for green projects.

As suggested by Gillan et al. (2021), the ESG literature on how ESG factors are related to a firm's market value or firm performance presents largely mixed evidence. While many studies show that there is a positive relationship between ESG performance and firm value or performance (e.g., Flammer, 2015), others document

\footnotetext{
$\overline{15}$ Some typical environmental and social risks for commercial properties include extreme weather events, climate changes, and natural disaster. Also, see an article from Bloomberg on Jan 15, 2020, titled "World's Biggest Long-Term Risks Are Environmental, WEF Says", and an article from The New York Times on Feb 20, 2020, titled "Climate Change Rises as a Public Priority. But It's More Partisan Than Ever.".

16 See Gillan et al. (2021) for an excellent review on ESG/CSR research in corporate finance. They also explain the differences between ESG and CSR in that ESG tends to be a more expansive term than CSR.
} 
the opposite results or mixed findings that ESG/CSR activities can add value to firms but only under certain conditions (e.g., Buchanan et al., 2018; Servaes \& Tamayo, 2013). Interestingly, Gillan et al. (2021) point out that the mixed evidence is partially due to the measurement problem of a firm's ESG performance, consistent with the findings of Christensen et al. (2021).

The research on the relations between ESG disclosure and firm performance or financing is also relatively limited, and the results often suggest a negative relationship. For instance, Jacobs et al. (2010) find that firms may experience negative abnormal returns when it is disclosed more ESG related information, e.g., firms take environmentally friendly actions or won green awards. They argue that it is costly for firms to make environmental improvements and comply with environmental and sustainability regulations. Christensen et al. (2021) document that greater ESG disclosure is associated with higher return volatility and a lower likelihood of issuing external financing. Thus, these studies suggest that disclosing ESG information can be a risky investment as disclosure often involves direct costs of information production and indirect costs of information auditing and monitoring.

Moreover, based on non-REIT samples, the evidence on the relation between ESG performance and ESG disclosure is inconsistent. Gelb and Strawser (2001) show a positive relationship between a firm's discretionary disclosure level and measures of CSR. In contrast, Matsumura et al. (2014) find that there is no association between inferior environmental performance and the likelihood of disclosing carbon emissions, conditional on firms taking environmentally damaging actions. Kim and Lyon (2015) argue that firms have incentives to misrepresent their ESG performance (i.e., disclosing the information either by exaggeration or undue modesty) based on which of their stakeholders are salient at a given point in time. In other words, firms with positive ESG performance might intentionally opt for low levels of ESG disclosure or even play down their ESG activities. They argue that the relation between firm performance and ESG disclosure depends on specific circumstances that the firm faces.

Besides, recent literature suggests that there is substantial disagreement across ESG data providers on ESG rating criteria, and many firms have struggled to identify which reporting framework or criteria to adopt in order to effectively disclose ESG information. For example, Ioannou and Serafeim (2017) indicate that the form and intensity of ESG (or CSR) reporting differ significantly across countries, industries, and firms. Christensen et al. (2021) show that there is a high degree of disagreement across ESG rating agencies on which ESG rating to give to individual firms. They find that greater ESG disclosure leads to greater ESG rating disagreement, and greater ESG disagreement is associated with higher return volatility and a lower likelihood of issuing external financing. Thus, given there is a lack of a standardized reporting framework on ESG disclosure and the high degree of ESG rating disagreement, more research is warranted on ESG disclosure.

The concept of ESG is relatively new in the REIT literature. There are several early studies on commercial properties documenting that green buildings, sustainability, energy-saving, and CSR are beneficial to operating performance of real estate firms. Several papers show that green buildings and sustainability can improve occupancy rates and property prices (Pivo \& Fisher, 2010; Wiley et al., 2010; and 
Reichardt et al., 2012). Using the CoStar database, Fuerst and McAllister (2011) show that eco-certified buildings receive a premium on their rents and selling prices, compared with other buildings in the same submarkets. Eichholtz et al. (2013) find that the energy efficiency of properties improves the level of rents and asset values. Newell and Lee (2012) document that the corporate governance factor (one of the three CSR dimensions) affects the performance of Australian REITs.

Recently, there is a new wave of research studying the impacts of green buildings and CSR on REIT financing and investment policies. Eichholtz et al. (2019) find that REITs with more buildings with LEED certification and Energy Star label have lower bond spreads and loans on environmentally certified buildings have lower mortgage rates. An and Pivo (2020) document that green buildings carry less default risk in the commercial mortgage-backed securities (CMBS) market. Note that similar to non-REIT firms, most of the literature on REIT ESG issues tend to focus on the effects of ESG performance, not on ESG disclosure.

While investors and lenders have paid close attention to REIT ESG disclosure recently, research on how it influences REIT debt financing and firm value has been quite limited. To a large extent, the limited research on this topic is due to a lack of data on REIT ESG disclosure, which is only available recently. There are only a few exceptions that provide some relevant evidence. For example, using a sample of 64 European public real estate firms from EPRA's sBPR database, Brounen et al. (2021) show that ESG performance (measured by the fraction of ESG data fields that show an improvement of the years) and ESG completeness (measured by the fraction of the filed data field) are positively correlated and that investors are willing to pay a premium for firms with higher sustainable ratings. Chiang et al. (2019) find that REITs disclose more CSR information when they have more investment opportunities. Overall, more research on how ESG disclosure is related to REIT financing and firm value is needed.

\section{The Related Literature on REIT Debt Financing}

The literature on debt financing of REITs and non-REIT firms is extensive. For instance, Allen et al. (2000) and Morri and Parri (2017) document that cost of debt of REITs decreases when there is a decrease in market interest rates. Deng et al. (2016) show that the cost of REIT investment-grade bonds is lower when the bonds are issued with covenants. More recently, Allen and Letdin (2020) provide evidence that the REIT-level cost of debt is lower than that at the property level. For nonREIT firms, Deng et al. (2007), Hann et al. (2013), and Aivazian et al. (2015) provide evidence that more diversified firms have lower bond spreads and loan rates.

There are several studies that examine the effects of transparency or information asymmetry on REIT capital market access or investment. For instance, Devos et al. (2019) find that information asymmetry of REITs is relatively low when they access the capital markets, using a measure based on bid-ask spreads. Their results suggest that REITs increase their disclosure when they plan to raise capital from the external capital markets, which in turn reduces the information asymmetry of REITs. An et al. (2011) find that corporate transparency is positively associated with 
REIT growth, based on two transparency proxies (stock price nonsynchronicity and discretionary accruals-based accounting measure). They argue that greater transparency facilitates REIT growth by relaxing information-based constraints on external financing. Kim et al. (2021) provide evidence on a positive correlation between changes to investment-risk disclosure and changes to actual investment, but no significant correlation between the changes to investment-risk disclosure and the market's perception of risk.

Unlike prior studies, the disclosure measure used in our paper is based on ESG information. To our knowledge, little research has been done on the relations between a REIT's ESG disclosure level and its cost of debt and financial flexibility.

\section{Differences Between ESG Disclosure Data and ESG Performance Data of REITs}

There are substantial differences between REIT ESG disclosure and the ESG performance data provided by GRESB. The ESG disclosure data evaluate what and how efficiently ESG-related information is disclosed by REITs, while the ESG performance data assess a REIT's ESG policies and activities based on a set of performance indicators. ${ }^{17}$

Specifically, ESG public disclosure evaluation is based on 22 indicators, consisting of four major aspects (i.e., governance of sustainability, implementation, operational performance, and stakeholder engagement). GRESB collect ESG disclosure data from publicly available sources (e.g., a firm's annual report or a stand-alone CSR/sustainability report or dedicated sections on the firm's website) and adds the information to the online GRESB Portal. The data is open for review from April through July each year, during which the listed firms can review and amend the data. All the updated data are then included in GRESB's validation process. Besides, only official, public disclosure by a firm is considered and private documents are not accepted.

To determine REIT ESG performance, seven sustainability aspects (i.e., management, policy \& disclosure, risks \& opportunities, monitoring \& EMS, performance, building certifications, and stakeholder engagement) and 50 indicators are evaluated by the GRESB, under peer group comparisons that are based on property types and locations. A similar validation process as that of ESG disclosure data mentioned above is applied for the ESG performance data. In short, the ESG performance data evaluate the ESG performance against a set of REIT ESG factors and activities, and ESG disclosure data reflect the level of transparency and effectiveness in reporting ESG-related information.

\footnotetext{
17 For more information on the ESG disclosure data, please see the following website: https://docum ents.gresb.com/generated_files/real_estate/2021/public_disclosure/reference_guide/complete.html.
} 


\section{Hypothesis Development}

Extant theory suggests that information asymmetry plays an important role in determining loan rate. Several original studies (e.g., Jaffee \& Russell, 1976; Stiglitz \& Weiss, 1981) demonstrate that there is an adverse-selection cost of bank lending when information asymmetry exists between lenders and borrowers. Specifically, these papers examine lender and borrower behaviors in a loan market where borrowers have more information about the likelihood of default than lenders do. As lenders cannot differentiate good borrowers and bad borrowers, they charge a higher loan rate to good borrowers to compensate the cost of evaluating lending risks and losses of lending to bad borrowers. Thus, asymmetric information between borrowers and lenders increases the cost of debt for all borrowers. Subsequent empirical work provides evidence on the effect of information asymmetry on cost of debt for individual firms. For instance, Derrien et al. (2016) show that greater information asymmetry increases a firm's cost of debt, using the loss of an analyst to identify exogenous increase in information asymmetry.

Meanwhile, Jensen and Meckling (1979) show that a firm can mitigate its information symmetry problems by providing detailed private information to its creditors. While a firm's managers can hide negative information to protect the current firm value or benefits, the firm will have to bear the risk of having a higher cost of debt in the long run. However, when a firm actively discloses its private information, the increased transparency and reputation can reduce its cost of debt. Sengupta (1998) provides a similar argument and finds evidence that disclosure rating is negatively related to a firm's cost of debt. The author argues that for firms consistently disclosure their private information, lenders will assign a lower probability that these firms withhold adverse information and charge them a lower risk premium. Moreover, Beatty et al. (2002) examine the effect of voluntary and mandatory accounting disclosure changes on cost of debt and find that loan rate is lower if the loan agreement contains covenants that are written to guarantee transparency.

As mentioned early, the ESG disclosure evaluation by GRESB is based on 22 indicators, covering four major aspects. Essentially, the ESG disclosure data measure a REIT's level of transparency in reporting ESG-related information. While ESG information is not typically reported in a firm's financial statements, ESG disclosure data deliver critical non-financial information that reflects the firm's longterm sustainability, stakeholder engagement, ethics and moral values. This valuable information can help lenders to assess a REIT's commitments and efforts to promote environmental, socially responsible policies and activities.

From a lender's perspective, ESG information has become increasingly important for lenders to make lending decisions. While lenders typically do not directly get involved in environmental issues, their reputation would be degraded if they act as facilitators for other firms' activities that cause environmental damages (Cowton \& Thompson, 2000). Lenders may also face default risk from borrowers who are confronted with financial consequences from their environmental and social damages. Thus, lenders are more likely to provide loans to firms with more ESG disclosure, charge a lower loan rate to environmentally and socially friendly firms. 
Considering the institutional idiosyncrasies of REITs, ESG disclosure is particularly relevant to facilitate REITs to access the capital markets. REITs hold little cash and must heavily depend on external capital markets to raise capital due to the dividend payout requirement (Dogan et al., 2019). Thus, it is vital for REITs to gain good access to the capital markets in order to stay competitive. As lenders have increasingly incorporated evaluation of ESG factors into their lending decisions, effective ESG disclosure helps mitigate information asymmetry between lenders and REITs and increase corporate transparency for REITs. Hence, we expect that REITs actively disclosing ESG information have lower firm-level cost of debt.

Previous literature (e.g., Kisgen, 2006; Qian \& Strahan, 2007) shows that corporate credit ratings heavily influence a firm's cost of borrowing. Also, a recent report by Fitch Ratings suggests ESG considerations have driven credit rating downgrades for firms under exceptional circumstances (Fitch, 2020). Thus, a positive relationship is expected between a REIT's credit ratings and ESG disclosure level.

Moreover, studies in corporate finance suggest that maintaining financial flexibility is a central issue for firms that hold little cash and heavily rely on external sources to fund investment and growth (e.g., Faulkender \& Wang, 2006). Recent research on REITs (Riddiough \& Steiner, 2020) highlight that retaining financial flexibility is important for REITs to address their future liquidity shocks, as REITs are capital intensive firms and are typically highly leveraged. They argue that use of unsecured debt, which typically includes debt covenants that place restrictions on a firm's total leverage, can help enhance financial flexibility of REITs. Thus, ESG disclosure level is expected to be positively related to REIT financial flexibility measures.

Regarding the relation between ESG disclosure and firm value, existing economic theory (e.g., Myers \& Majluf, 1984) suggests that information asymmetry between investors and managers influences firm value, and there is a similar adverse-selection cost of raising external equity. In contrast, improving corporate transparency helps firms to increase firm value. For instance, Diamond (1985) proposes a general equilibrium model and demonstrates that active disclosure of information makes all shareholders better off. The benefits occur because of explicit information cost savings and improved risk sharing. Diamond and Verrecchia (1991) show that effective disclosing public information can reduce a firm's cost of equity capital by increasing demand from large investors due to the enhanced liquidity of the firm's securities.

Since ESG disclosure data reflect the critical aspects of the REIT operations and business practices, and investors recognize the importance of ESG disclosure, greater ESG disclosure can help mitigate the information asymmetry problems and improve corporate transparency for REITs. Moreover, recent industry reports suggest that effective ESG disclosure by a REIT can influence the firm's operations and performance. As stated in the 2020 ESG Industry report by Nareit, ${ }^{18}$ "Organizations that proactively and effectively manage and disclose ESG risks are more likely to meet or exceed disclosure requirements and regulations, have access to more capital due to increased transparency with investors and lenders, and engage in more

\footnotetext{
18 The REIT industry ESG report is available from the following website: www.reit.com/sites/default/ files/media/ DataResearch/Nareit_ESG_Report_2020_Final.pdf.
} 
informed strategic planning." Thus, we expect that effective ESG disclosure have a positive relationship with firm value of REITs.

To sum up, effective ESG disclosure by a REIT provides valuable information to its lenders, investors and other stakeholders, which mitigates the information asymmetry problems and improve corporate transparency. We expect that REITs actively disclosing ESG information have lower cost of debt, greater financial flexibility and higher firm value. Nevertheless, given there is mixed evidence in the literature on the relationships and it is costly for firms to disclose ESG information and comply with environmental and sustainability regulations, ultimately it is an empirical question as to how ESG disclosure is related to REIT debt financing and firm value.

\section{Data, Variable Construction, and the Sample}

\section{Data Sources}

To conduct the empirical analysis on the effects of ESG disclosure level on REIT debt financing and firm value, we collected data from the S\&P Global Market Intelligence database, which started to report REIT ESG disclosure data in 2019. GRESB collects ESG disclosure data from publicly available sources and all the data are updated in GRESB's validation process. For equity REITs around the world, we collect the 2019 and 2020 firm-level ESG public disclosure level, financial data and related information. ${ }^{19}$ REITs with missing total assets and ESG disclosure level are discarded.

\section{Variable Construction}

The ESG disclosure level information recorded in the S\&P Global is provided by the Global Real Estate Sustainability Benchmark (GRESB). ${ }^{20}$ The ESG disclosure level reflects the level of transparency of a REIT in reporting their ESG-related information and performance ${ }^{21}$. For example, some of the questions asked in GRESB disclosure evaluation system are: Does the entity disclose specific environmental objectives? Any policy/policies that address(es) environmental issues? If yes, please disclose where the information can be found URL? GRESB sets up a point system based on certain criteria related to a firm's disclosure of ESG-related information and performance. The maximum ESG disclosure point is 70, based on four aspects: governance of sustainability, implementation, operational performance and stakeholder engagement. A firm's ESG disclosure ratings are expressed in five levels:

\footnotetext{
19 Since the ESG disclosure level data are only available in the S\&P Global database in 2019, the analysis is based on firm year observations in 2019 and 2020.

20 The GRESB assesses and benchmarks the Environmental, Social and Governance (ESG) performance of property companies, REITs, funds, and developers. Website: www.gresb.com/

21 To learn more, visit GRESB's 2019 Public Disclosure Reference Guide at https://documents.gresb. com/generated_files/real_estate/2019/public_disclosure/reference_guide/complete.html
} 
$\mathrm{A}=57-70$ points, $\mathrm{B}=43-56, \mathrm{C}=27-42, \mathrm{D}=15-28$, and $\mathrm{E}=0-14$. In our analysis, the A-E levels of ESG disclosure are assigned as 5 for Level A (the highest level), 4 for Level B, 3 for Level C, 2 for Level D, and 1 for Level E (the lowest level). Thus, the ESG disclosure measure is a categorical variable in the regressions. The ESG disclosure level is the key independent variable in this study.

We use two measures to assess the cost of debt of REITs. The first is the weighted average interest rate, which is provided by S\&P Global. The second is the interest to debt ratio, which is calculated as a REIT's interest expense divided by its total debt, as in Ambrose et al. (2005). Our primary measure to assess financial flexibility of REITs is non-secured debt to total debt ratio. Riddiough and Steiner (2020) suggest that use of unsecured debt helps REITs to enhance their financial flexibility. Also, most of the long-term debt of REITs are long-term unsecured debt (besides secured mortgage debt) (Riddiough \& Steiner, 2020). So, we use long-term debt to total debt ratio as an additional proxy for financial flexibility. We expect that the higher (lower) the non-secured debt to total debt ratio and the higher (lower) long-term debt to total debt ratio, the more (less) financial flexibility the REIT has.

As the corporate credit ratings heavily affect a firm's cost of financing (Kisgen, 2006), we include the credit ratings of REITs in our analyses. Specifically, we assign the credit rating value of a REIT as 5 if its S\&P's rating $=\mathrm{A}+$, A or A- or Moody's rating $=\mathrm{A} 1, \mathrm{~A} 2$, or $\mathrm{A} 3$ (the highest rating), 4 if its $\mathrm{S} \& \mathrm{P}$ 's $=\mathrm{BBB}+, \mathrm{BBB}$ or BBB- or Moody's $=\mathrm{Baa} 1, \mathrm{Baa} 2$, or Baa3, 3 if its S\&P's $=\mathrm{BB}+, \mathrm{BB}$ or BB- or Moody's $=\mathrm{Ba} 1, \mathrm{Ba} 2$, or Ba3, 2 if its S\&P's $=\mathrm{B}+, \mathrm{B}$ or B- or Moody's $=\mathrm{B} 1, \mathrm{~B} 2$, or $\mathrm{B} 3$, and 1 if its $\mathrm{S} \& \mathrm{P}$ 's $=\mathrm{CCC}+, \mathrm{CCC}$ or CCC - or Moody's $=\mathrm{Caa} 1, \mathrm{Caa} 2$, or $\mathrm{Caa} 3$ (the lowest rating). Firms with lower credit ratings would bear a higher cost of borrowing than their pairs with better credit ratings.

We adopt two measures to assess firm value of REITs. The first is the market to book equity ratio, which is the market capitalization divided by total equity (Beracha et al., 2019). The second is firm $Q$, which is the ratio of each REIT's market capitalization plus total assets minus total equity to total assets (Lamont \& Polk, 2002). Market to book equity ratios and firm $Q$ that are negative or greater than 10 are replaced with missing values.

Several commonly used control variables in REIT literature are adopted, including the natural logarithm of the book value of assets ( $\log T A)$, the natural logarithm of one plus the number of years since REIT status established (LogAge), the growth rate of total assets (AssetsGrowth), the ratio of net operating income to total assets (NOI/TA), the ratio of total debt to total equity (Leverage), and the ratio of cash and cash equivalents to the book value of assets (CashStock). The definitions for the variables mentioned above are also listed in Table 1.

\section{Sample Statistics}

In our sample, firm-year observations without total assets and ESG disclosure level are excluded. To reduce the effect of outliers in the data, the numeric variables are winsorized at the $1 \%$ and $99 \%$ tails of the distributions. The sample consists of 706 firm-year observations for 376 REITs around the world. Figure 1 presents the 


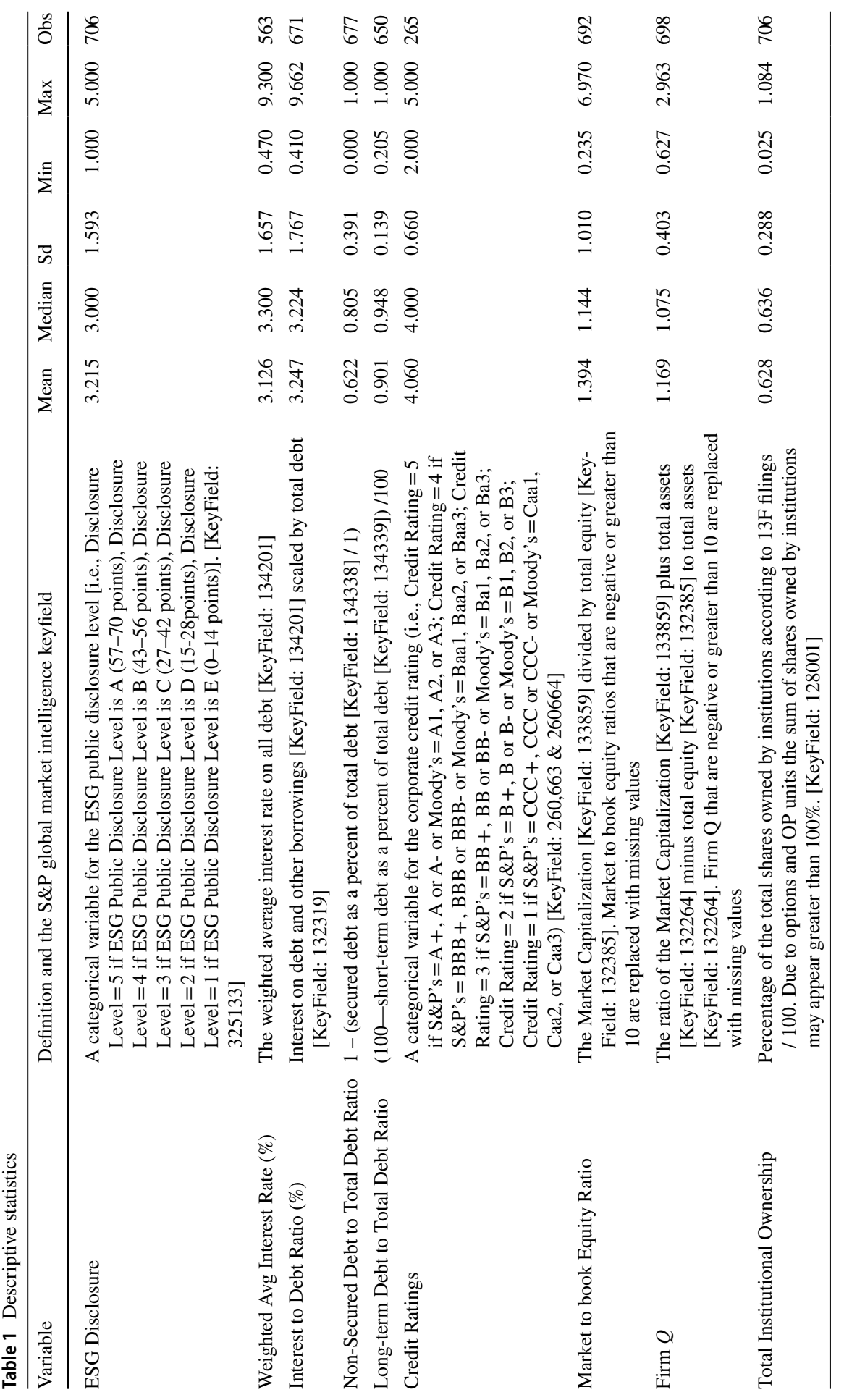




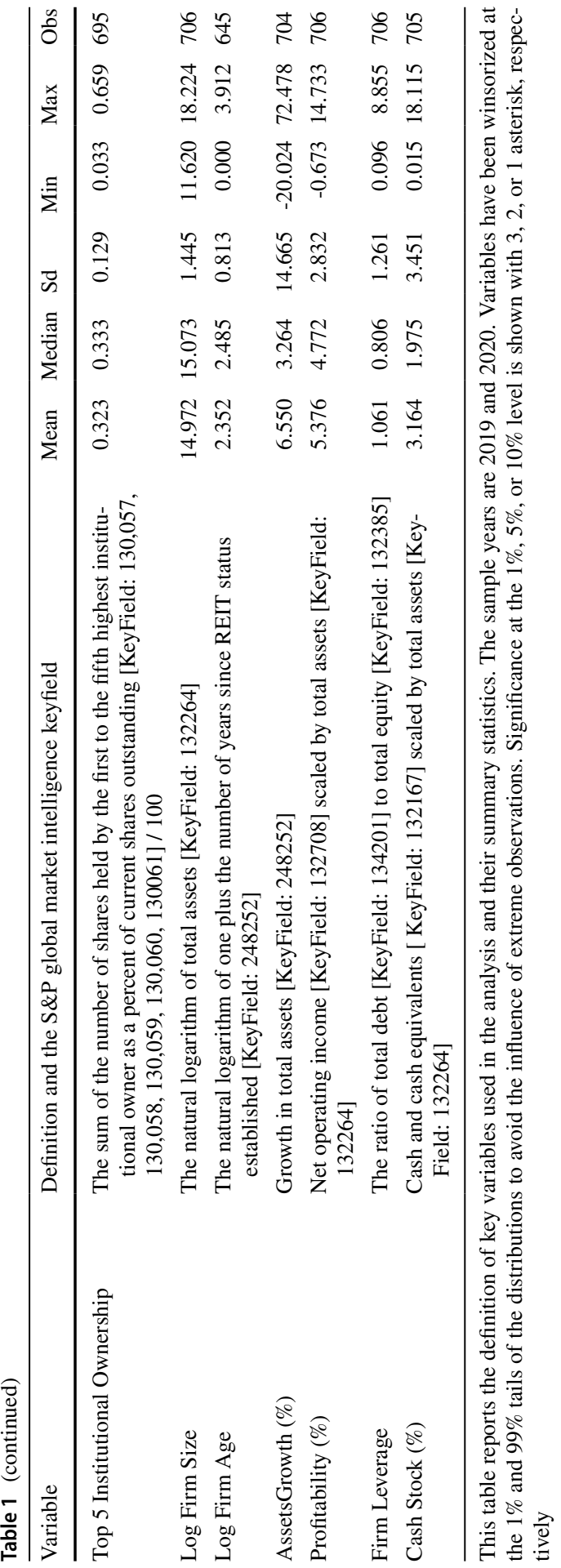



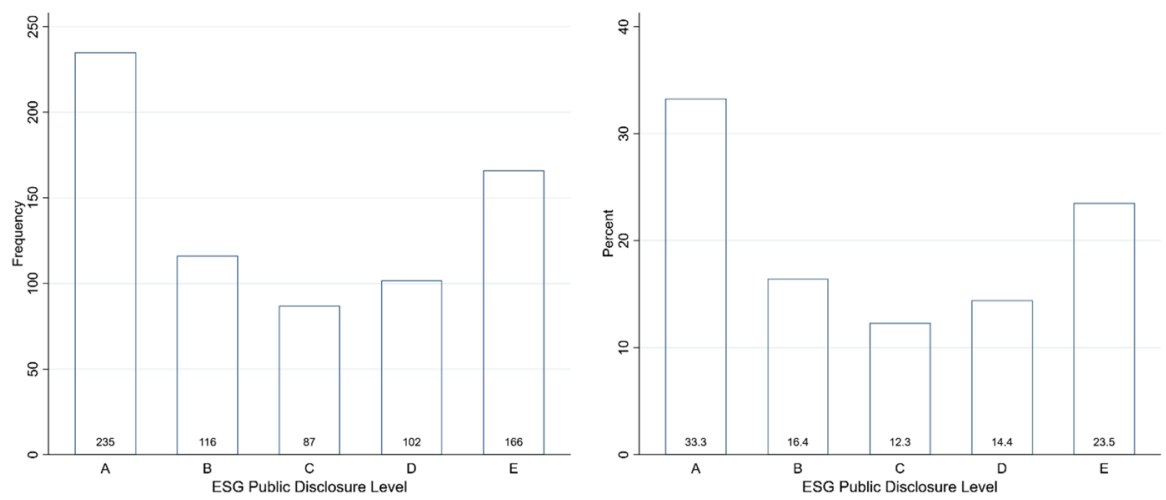

Fig. 1 ESG disclosure level-frequency and percent. This figure presents the frequency and percent of the 2019 \& 2020 GRESB ESG public disclosure evaluation on REITs. The ESG Disclosure Level is a categorical variable (i.e., Level $\mathrm{A}=57-70$ points, $\mathrm{B}=43-56, \mathrm{C}=27-42, \mathrm{D}=15-28$, and $\mathrm{E}=0-14$, as defined by GRESB). Variables have been winsorized at the $1 \%$ and $99 \%$ tails of the distributions to avoid the influence of extreme observations
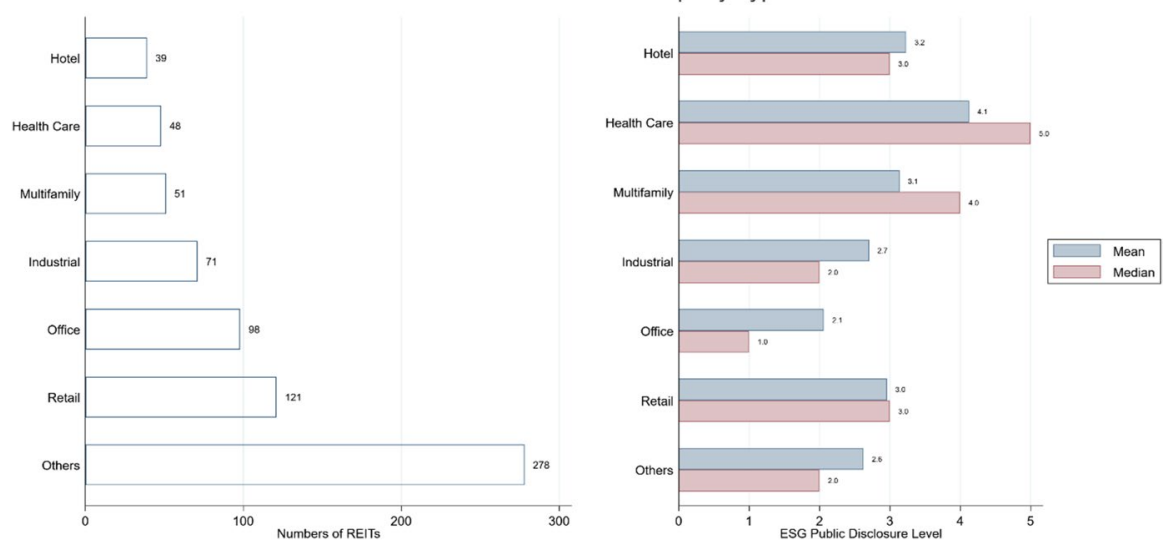

Fig. 2 ESG disclosure in each property type. This figure presents the numbers of REITs in the 2019 \& 2020 GRESB ESG public disclosure evaluation in each property type and the average and median ESG public disclosure evaluation in each property type. A REIT's ESG disclosure ratings are expressed in five levels: Disclosure Level $=5$ (the highest level) if ESG Public Disclosure Level is A (57-70 points), Disclosure Level $=4$ if ESG Public Disclosure Level is B (43-56 points), Disclosure Level = 3 if ESG Public Disclosure Level is C (27-42 points), Disclosure Level = 2 if ESG Public Disclosure Level is D (15-28 points), Disclosure Level $=1$ (the lowest level) if ESG Public Disclosure Level is E (0-14 points)

frequency and percent of the 2019 and 2020 GRESB ESG public disclosure evaluation in the sample. The ESG disclosure level is a categorical variable. In the sample, 235 firm-year observations (33\%) have an ESG disclosure level as A, 116 firm-year observations (16\%) are in level B, 87 firm-year observations (12\%) are in level C, 102 firm-year observations (14\%) are in level D, and 166 firm-year observations (24\%) are in level E. 
Figure 2 presents the numbers of REITs in the disclosure data in each property type and the average and median ESG public disclosure evaluation in each property type. $^{22}$ The healthcare REITs have the highest average disclosure level (4.1), while the office REITs have the lowest disclosure level (2.1).

Figure 3 presents the numbers of REITs in the ESG disclosure data in each global region and the average and median ESG public disclosure evaluation in each global region. In the sample, there are 326 firm-year observations for United States and Canada REITs, 208 firm-year observations for Asia-Pacific REITs, 141 firm-year observations for Europe REITs, 26 firm-year observations for Africa REITs, and 9 firm-year observations for Latin America and Caribbean REITs. At the regional level, US and Canada REITs outperform others in terms of average ESG disclosure level and on average Asia-Pacific REITs have the lowest disclosure level (2.1).

Table 1 reports descriptive statistics for the variables used in the analysis, along with their definitions. A typical REIT has the mean and median ESG disclosure level of 3 [i.e., 27-42 points (Level C)]. Regarding the two cost of debt measures, the mean and median of the interest to debt ratio are $3.13 \%$ and $3.30 \%$, while the mean and median of the weighted average interest rate are $3.25 \%$ and $3.22 \%$, respectively. In terms of the two financial flexibility measures, the mean and median of non-secured debt to total debt ratio are $62.2 \%$ and $80.5 \%$, while the mean and median of long-term debt to total debt ratio are $90.1 \%$ and $94.8 \%$, respectively. The corporate credit ratings have a mean and median of 4 (i.e., BBB,$+ \mathrm{BBB}$ or BBB- in the S\&P's or Baa1, Baa2, or Baa3 in the Moody's). Moreover, the market to book equity ratio of REITs has a mean of 1.39 and a median of 1.14, while firm $Q$ has a mean of 1.17 and a median of 1.08 .

\section{Empirical Methods}

To show the difference between the cost of debt of the high ESG disclosure REITs and that of the low ESG disclosure REITs, we regress the cost of debt measures on REIT ESG disclosure level in the cross-section, with heteroscedasticity-robust standard errors that are clustered at the firm-level, as in Eq. (1).

$$
\text { Cost of } \text { Debt }_{i}=\beta_{0}+\beta_{1} \text { ESG Disclosure }_{i}+\text { Controls }_{i}+\eta_{p}+\gamma_{g}+\varepsilon_{i}
$$

where $i$ is the subscript referring to a REIT, CostofDebt is either interest to debt ratio or weighted average interest rate, ESGDisclosure is a categorical variable, which is expressed in A-E levels, $\eta_{p}$ represents real estate property type fixed effects, $\gamma_{g}$ represents global region fixed effects, $\beta_{0}$ and $\varepsilon$ represent the constant and the error term, respectively. The control variables in the regression include firm size, firm age, asset growth, financial performance, leverage, and cash stock. The variables included in Eq. (1) are as defined earlier in the text and Table 1.

\footnotetext{
22 Property type refers to REIT's type of real estate property, which is determined by the tenant's uses of the property. [S\&P Global KeyField: 113553]. Property types are regrouped into seven categories: office, industrial, retail, hotel, multifamily, health care and others.
} 


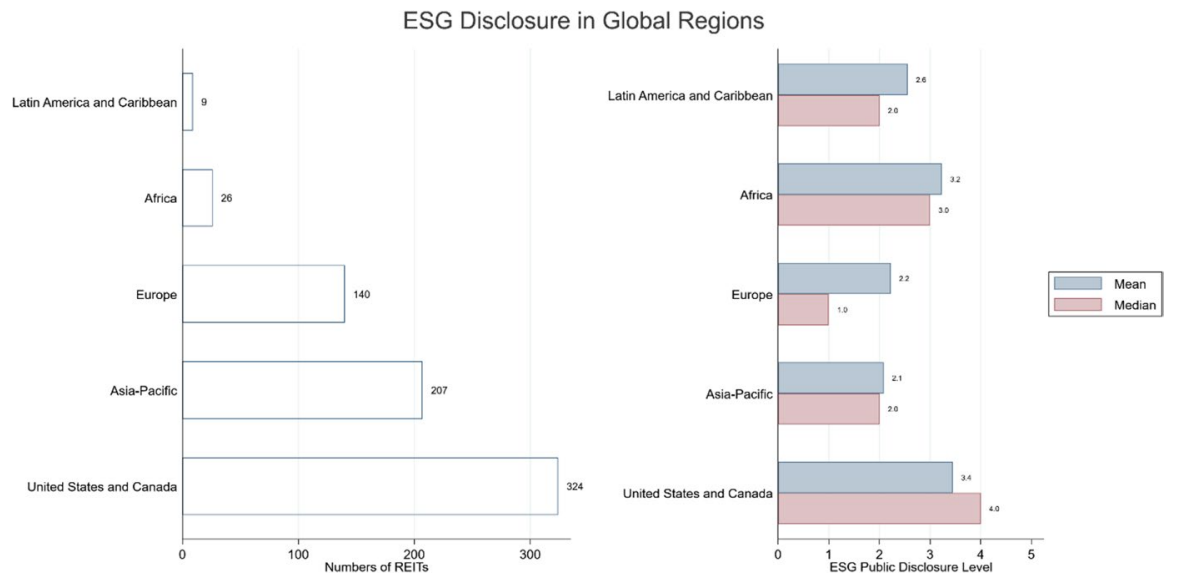

Fig. 3 ESG disclosure in global regions. This figure presents the numbers of REITs in the 2019 \& 2020 GRESB ESG public disclosure evaluation in each global region and the average and median ESG public disclosure evaluation in each global region. A REIT's ESG disclosure ratings are expressed in five levels: Disclosure Level $=5$ (the highest level) if ESG Public Disclosure Level is A (57-70 points), Disclosure Level $=4$ if ESG Public Disclosure Level is B (43-56 points), Disclosure Level= 3 if ESG Public Disclosure Level is C (27-42 points), Disclosure Level=2 if ESG Public Disclosure Level is D (15-28points), Disclosure Level = 1 (the lowest level) if ESG Public Disclosure Level is E (0-14 points)

To examine whether ESG disclosure enhances REITs' financial flexibility, we replace the dependent variable in Eq. (1) as the two measures of financial flexibility (i.e., non-secured debt to total debt ratio and long-term debt to total debt ratio). The corporate long-term credit ratings of a firm from credit rating agencies are based on formal, independent assessments of the firm's ability to service its debt obligations. Firms with a higher credit rating generally have a lower cost of borrowing (Qian \& Strahan, 2007). Hence, we examine how ESG disclosure level is related to a REIT's credit rating, by replacing the dependent variable in Eq. (1) as the corporate credit rating measure.

As discussed early, it is interesting to examine whether investors value a REIT's ESG disclosure level. If investors do value the information from REITs' ESG disclosure, one would expect a positive relationship between a REIT's market valuation and its ESG disclosure level. Alternatively, if investors view ESG disclosure as "cheap talk" or "greenwashing" (Kim \& Lyon, 2015), a REIT's firm value may not be positively related to ESG disclosure. To evaluate whether the ESG disclosure level of a REIT is a significant factor for its market value, we replace the dependent variables in Eq. (1) as REITs' firm value (i.e., market to book equity ratio and firm $Q)$.

Moreover, we adopt a propensity score matching model to address the omitted variable issue. Specifically, REITs with the highest ESG disclosure level (Level A) are classified as high -ESG disclosure group (i.e., the treatment group). We compare the cost of debt for the high-ESG disclosure REITs with other REITs that have been matched via the propensity score matching procedure. The control variables include firm size, firm age, asset growth, financial performance, leverage, and cash stock. 


\section{Main Results}

\section{Cost of Debt}

Table 2 presents the results of Eq. (1), which examines the relationship between ESG disclosure and cost of $\mathrm{debt}^{23}$. When the dependent variable is the weighted average interest rate, as in Columns (1) and (2), the estimated coefficients for ESG disclosure level C, D and E are 0.508, 0.715 and 1.067, respectively ${ }^{24}$. All three coefficients display statistical significance at the $1 \%$ level. The baseline results suggest that the cost of debt of REITs is higher when they have lower levels of ESG disclosure. Next, the interest to debt ratio is used as an alternative proxy for the cost of debt. Results from Columns (3) and (4) indicate that REITs with lower disclosure levels generally pay more interest payments on their debts. Specifically, the coefficients ( $t$-statistics) of ESG disclosure level C, D and E are 0.608 (4.06), 0.885 (3.92) and 1.371 (5.39), respectively.

In addition to the variable of interest, cost of debt of REITs is positively associated with firm size and profitability, and negatively associated with firm age and assets growth. Overall, the results show a negative association between ESG disclosure and cost of debt of REITs, i.e., the more ESG disclosure the REITs have, the lower weighted average interest rate and interest to debt ratios they have, after controlling for firm characteristics including size, age, growth, performance, leverage, and cash holdings. The results confirm the hypothesis that REITs with higher ESG disclosure levels have lower cost of debt, which is likely because "environmentally friendly" and "socially responsible" REITs are considered more favorable by lending institutions.

\section{Financial Flexibility}

Next, we explore the correlation between REITs' financial flexibility (measured by non-secured debt to total debt ratio and long-term debt to total debt ratio) and their ESG disclosure, controlling for firm size, firm age, firm growth, capital structure, operational performance, and cash stock. Table 3 reports the results. When the nonsecured debt to total debt ratio is used as the dependent variable, the coefficient of ESG disclosure level D is -0.180 with a $t$-statistic of -3.05 , while the coefficient of ESG disclosure level $\mathrm{E}$ is -0.236 with a $t$-statistic of -4.12 . Regarding the control variables, the non-secured debt to total debt ratio of REITs is positively related to firm size and firm growth and negatively related to leverage. This baseline result

\footnotetext{
23 Property type and global region fixed effects are included. $t$-statistics are based on standard errors that are clustered at the firm level and are heteroscedasticity-robust. ESG disclosure level A is set as the base level and omitted in the regression.

24 That is, compared to the weighted average interest rate in Group 1 (ESG Disclosure Level-A), we would expect the weighted average interest rate in Group 5 (ESG Disclosure Level-E) to be 1.067\% higher, on average.
} 
Table 2 Cost of debt and ESG disclosure

\begin{tabular}{|c|c|c|c|c|}
\hline \multirow[b]{3}{*}{ Variables } & \multicolumn{2}{|c|}{ Weighted average interest rate } & \multicolumn{2}{|c|}{ Interest to-debt ratio } \\
\hline & (1) & (2) & (3) & (4) \\
\hline & Coefficient & $t$-Statistic & Coefficient & $t$-Statistic \\
\hline ESG disclosure level-B & $0.427 * * *$ & 3.00 & $0.439 * * *$ & 3.12 \\
\hline ESG disclosure level-C & $0.508 * * *$ & 2.88 & $0.608 * * *$ & 4.06 \\
\hline ESG disclosure level-D & $0.715 * * *$ & 3.57 & $0.885 * * *$ & 3.92 \\
\hline ESG disclosure level-E & $1.067 * * *$ & 3.67 & $1.371 * * *$ & 5.39 \\
\hline Log firm size & $0.330 * * *$ & 4.82 & $0.286^{* * *}$ & 4.44 \\
\hline Log firm age & $-0.193 * *$ & -2.39 & $-0.141^{*}$ & -1.73 \\
\hline Firm growth & $-0.009 * *$ & -2.14 & $-0.029 * * *$ & -6.09 \\
\hline Profitability & $0.067 * *$ & 2.41 & $0.069^{* *}$ & 2.49 \\
\hline Firm leverage & -0.022 & -0.57 & -0.064 & -1.58 \\
\hline Cash stock & -0.023 & -1.45 & 0.019 & 0.91 \\
\hline Constant & 1.330 & 0.89 & 1.528 & 1.06 \\
\hline Observations & 511 & & 611 & \\
\hline$R$-squared & 0.704 & & 0.622 & \\
\hline Property type FE & YES & & YES & \\
\hline Global region FE & YES & & YES & \\
\hline
\end{tabular}

This table reports the regression results of the cost of debt measures (i.e., the weighted average interest rate and the ratio of Interest to-Debt ratio) in REITs on ESG disclosure level, which is a categorical variable [i.e., Disclosure Level $=5$ if ESG Public Disclosure Level is A (57-70 points), Disclosure Level $=4$ if ESG Public Disclosure Level is B (43-56 points), Disclosure Level $=3$ if ESG Public Disclosure Level is C (27-42 points), Disclosure Level $=2$ if ESG Public Disclosure Level is D (15-28points), Disclosure Level $=1$ if ESG Public Disclosure Level is E (0-14 points)]. Standard errors are clustered at the firm level and are heteroscedasticity-robust. Public Disclosure Level A is set as the base level and omitted in the regression. $t$-statistics are reported in brackets. The coefficients of property types and global regions are suppressed from reporting. Significance at the $1 \%, 5 \%$, or $10 \%$ level is shown with 3,2, or 1 asterisk, respectively

suggests that REITs' non-secured debt to total debt ratios are higher when they have higher levels of ESG disclosure.

When the long-term debt to total debt ratio is used as the dependent variable, the estimated coefficient of ESG disclosure level D is -0.064 with a $t$-statistic of -2.36, while the coefficient of ESG disclosure level $\mathrm{E}$ is -0.057 with a $t$-statistic of -2.69 . The results show that the long-term debt to total debt ratio of REITs is positively related to firm growth and negatively related to leverage and firm age. Taken together, the results suggest that REITs ESG disclosure levels enhance their financial flexibility.

\section{Corporate Credit Ratings}

Table 4 presents the regression results, in which the dependent variable is a categorical variable for the corporate credit rating (ranging from 5 to 1 ). The 
Table 3 Financial flexibility and ESG disclosure

\begin{tabular}{|c|c|c|c|c|}
\hline & \multicolumn{2}{|c|}{ Non-secured debt to total debt ratio } & \multicolumn{2}{|c|}{$\begin{array}{l}\text { Long-term debt to total debt } \\
\text { ratio }\end{array}$} \\
\hline & (1) & (2) & (3) & (4) \\
\hline Variables & Coefficient & $t$-Statistic & Coefficient & $t$-Statistic \\
\hline ESG Disclosure Level—B & $-0.076^{*}$ & -1.67 & -0.020 & -1.40 \\
\hline ESG Disclosure Level-C & -0.083 & -1.64 & $-0.040 * *$ & -2.11 \\
\hline ESG Disclosure Level—D & $-0.180^{* * *}$ & -3.05 & $-0.064 * *$ & -2.36 \\
\hline ESG Disclosure Level—E & $-0.236^{* * *}$ & -4.12 & $-0.057 * * *$ & -2.69 \\
\hline Log Firm Size & -0.009 & -0.60 & -0.006 & -0.99 \\
\hline Log Firm Age & $0.088 * * *$ & 3.44 & $-0.035 * * *$ & -2.96 \\
\hline Firm Growth & $0.002^{*}$ & 1.95 & $0.002 * * *$ & 3.54 \\
\hline Profitability & 0.014 & 1.62 & 0.005 & 1.62 \\
\hline Firm Leverage & $-0.034 * * *$ & -2.63 & $-0.015^{*}$ & -1.94 \\
\hline Cash Stock & -0.005 & -0.87 & -0.003 & -0.94 \\
\hline Constant & 0.374 & 1.27 & $0.971 * * *$ & 7.24 \\
\hline Observations & 617 & & 588 & \\
\hline$R$-squared & 0.294 & & 0.195 & \\
\hline Property Type FE & YES & & YES & \\
\hline Global Region FE & YES & & YES & \\
\hline
\end{tabular}

This table reports the regression results of the financial flexibility measures (i.e., the ratio of non-secured debt to total debt and the ratio of long-term debt to total debt) in REITs on ESG disclosure level, which is a categorical variable [i.e., Disclosure Level $=5$ if ESG Public Disclosure Level is A (57-70 points), Disclosure Level $=4$ if ESG Public Disclosure Level is B (43-56 points), Disclosure Level $=3$ if ESG Public Disclosure Level is C (27-42 points), Disclosure Level=2 if ESG Public Disclosure Level is D (15-28points), Disclosure Level $=1$ if ESG Public Disclosure Level is E (0-14 points)]. Standard errors are clustered at the firm level and are heteroscedasticity-robust. Public Disclosure Level A is set as the base level and omitted in the regression. $t$-statistics are reported in brackets. The coefficients of property types and global regions are suppressed from reporting. Significance at the $1 \%, 5 \%$, or $10 \%$ level is shown with 3,2 , or 1 asterisk, respectively

results show that the higher value of this categorical variable (e.g., a rating of $5)$, the stronger the credit ratings. The estimated coefficients of ESG disclosure levels (from B to E) are all negative. Specifically, the estimated coefficients of ESG disclosure level D and F are -0.256 and -0.605 , respectively, with statistical significance at the $5 \%$ or $1 \%$ levels. Besides, older REITs generally have higher corporate credit ratings. These results indicate that REITs with the highest ESG disclosure level (i.e., level A) generally have better corporate long-term ratings, which is consistent with the results on cost of debt and financial flexibility, as firms with good credit ratings generally have better access to the capital markets. In other words, the positive relation between ESG disclosure and credit ratings provides additional evidence on the relation between ESG disclosure and REIT debt financing. 
Table 4 Corporate credit ratings and ESG disclosure

(1)

\begin{tabular}{|c|c|c|}
\hline Variables & Coefficient & $t$-Statistic \\
\hline ESG Disclosure Level—B & -0.149 & -1.49 \\
\hline ESG Disclosure Level-C & $-0.190^{*}$ & -1.82 \\
\hline ESG Disclosure Level—D & $-0.256^{* *}$ & -2.03 \\
\hline ESG Disclosure Level-E & $-0.605^{* * *}$ & -4.66 \\
\hline Log Firm Size & 0.044 & 1.10 \\
\hline Log Firm Age & $0.235^{* * *}$ & 3.75 \\
\hline Firm Growth & 0.002 & 0.58 \\
\hline Profitability & 0.024 & 1.25 \\
\hline Firm Leverage & -0.075 & -1.40 \\
\hline Cash Stock & 0.009 & 0.71 \\
\hline Constant & $2.164 * *$ & 2.53 \\
\hline Observations & 245 & \\
\hline$R$-squared & 0.535 & \\
\hline Property Type FE & YES & \\
\hline Global Region FE & YES & \\
\hline
\end{tabular}

This table reports the relationship between corporate credit rating and ESG disclosure level in REITs. Panel A presents the two-way table of frequency counts on corporate credit rating and ESG disclosure level. Panel B reports the results of regressing corporate credit rating on ESG disclosure level. Corporate credit rating is a categorical variable (i.e., Credit Rating $=5$ if S\&P's $=\mathrm{A}+$, A or A- or Moody's $=\mathrm{A} 1, \mathrm{~A} 2$, or A3; Credit Rating $=4$ if $\mathrm{S} \& \mathrm{P}$ 's $=\mathrm{BBB}+, \mathrm{BBB}$ or BBB- or Moody's $=\mathrm{Baa} 1$, $\mathrm{Baa}$, or Baa3; Credit Rating $=3$ if S\&P's $=\mathrm{BB}+, \mathrm{BB}$ or BB- or Moody's $=\mathrm{Ba} 1, \mathrm{Ba}$, or Ba3; Credit Rating = 2 if S\&P's $=\mathrm{B}+, \mathrm{B}$ or B- or Moody's = B1, B2, or B3; Credit Rating =1 if S\&P's =CCC + , $\mathrm{CCC}$ or CCC- or Moody's=Caa1, Caa2, or Caa3). ESG disclosure level is also a categorical variable [i.e., Disclosure Level $=5$ if ESG Public Disclosure Level is A (57-70 points), Disclosure Level=4 if ESG Public Disclosure Level is B (43-56 points), Disclosure Level = 3 if ESG Public Disclosure Level is C (27-42 points), Disclosure Level $=2$ if ESG Public Disclosure Level is D (15-28points), Disclosure Level= 1 if ESG Public Disclosure Level is E (0-14 points)]. Standard errors are clustered at the firm level and are heteroscedasticity-robust. Public Disclosure Level A is set as the base level and omitted in the regression. $t$-statistics are reported in brackets. The coefficients of property types and global regions are suppressed from reporting. Significance at the $1 \%, 5 \%$, or $10 \%$ level is shown with 3, 2, or 1 asterisk, respectively

\section{Firm Value}

The empirical evidence on the relationship between ESG disclosure and firm value in the REIT sample is reported in Table 5. Columns (1) and (2) show the regression results with market to book equity ratio as the dependent variable. The estimated coefficients of ESG disclosure level B-E variables are all negative. Specifically, the estimated coefficients of ESG disclosure level C-E are -0.160 , -0.374 and -0.341 . All display statistical significance at the $10 \%$ or $1 \%$ level. Columns (3) and (4) report the results with firm $Q$ as the dependent variable. The results are consistent. Also, REIT value is positively associated with firm 
Table 5 Firm value and ESG disclosure

\begin{tabular}{|c|c|c|c|c|}
\hline \multirow[b]{3}{*}{ Variables } & \multicolumn{2}{|c|}{ Market to book equity ratio } & \multicolumn{2}{|l|}{ Firm $Q$} \\
\hline & (1) & (2) & (3) & (4) \\
\hline & Coefficient & $t$-Statistic & Coefficient & $t$-Statistic \\
\hline ESG Disclosure Level—B & -0.083 & -1.04 & $-0.066^{* *}$ & -2.10 \\
\hline ESG Disclosure Level-C & $-0.160^{*}$ & -1.72 & $-0.080 * *$ & -2.22 \\
\hline ESG Disclosure Level—D & $-0.374 * * *$ & -3.35 & $-0.130 * * *$ & -3.14 \\
\hline ESG Disclosure Level—E & $-0.341 * * *$ & -3.42 & $-0.148 * * *$ & -3.59 \\
\hline Log Firm Size & -0.012 & -0.39 & $-0.022 * *$ & -2.00 \\
\hline Log Firm Age & $0.103 *$ & 1.81 & $0.054 * *$ & 2.56 \\
\hline Firm Growth & $0.015^{* * *}$ & 7.31 & $0.007 * * *$ & 6.90 \\
\hline Profitability & $0.211 * * *$ & 6.68 & $0.075 * * *$ & 6.42 \\
\hline Firm Leverage & $0.176^{* *}$ & 2.53 & 0.011 & 0.52 \\
\hline Cash Stock & $0.041^{* *}$ & 2.30 & $0.008^{* *}$ & 2.02 \\
\hline Constant & -0.438 & -0.62 & $0.821 * * *$ & 3.33 \\
\hline Observations & 629 & & 635 & \\
\hline$R$-squared & 0.513 & & 0.530 & \\
\hline Property Type FE & YES & & YES & \\
\hline Global Region FE & YES & & YES & \\
\hline
\end{tabular}

This table reports the regression results of the market valuation measures (i.e., market to book equity ratio and firm $Q$ ) in REITs on ESG disclosure level, which is a categorical variable [i.e., Disclosure Level $=5$ if ESG Public Disclosure Level is A (57-70 points), Disclosure Level=4 if ESG Public Disclosure Level is B (43-56 points), Disclosure Level = 3 if ESG Public Disclosure Level is C (27-42 points), Disclosure Level $=2$ if ESG Public Disclosure Level is D (15-28points), Disclosure Level $=1$ if ESG Public Disclosure Level is E (0-14 points)]. Standard errors are clustered at the firm level and are heteroscedasticity-robust. Public Disclosure Level A is set as the base level and omitted in the regression. $t$-statistics are reported in brackets. The coefficients of property types and global regions are suppressed from reporting. Significance at the $1 \%, 5 \%$, or $10 \%$ level is shown with 3,2, or 1 asterisk, respectively

age, firm growth, profitability, leverage and cash stock, while negatively associated with firm size. Overall, the results indicate that the market valuation for REITs with the highest ESG disclosure level (i.e., level A) is generally higher than REITs with lower ESG disclosure levels, suggesting that REIT shareholders do value the information from a REIT's ESG disclosure.

Collectively, the results presented thus far provide evidence that REITs' cost of debt, financial flexibility, corporate credit ratings and market value are related to ESG disclosure with statistical and economic significance. The results are robust when we control for other factors that are related to REITs' financing and valuation, such as firm size, firm age, firm growth, profitability, leverage, and cash stock. 


\section{Additional Analyses}

In this section, we conduct robustness checks to support the main results in Sect. 5. The additional analyses include: (1) using a propensity score matching model to address the omitted variable issue, (2) studying the effects of 2019 ESG disclosure on 2020 firm value, (3) examining the relationship between ESG disclosure and institutional ownership, and (4) examining the differences between REITs with and without ESG disclosure ratings.

\section{The Propensity Score Matching Results}

Table 6 present the propensity score matching results ${ }^{25}$. Panel A reports the logit regression results that the probability (i.e., the propensity score) is the predicted value. In the pre-match sample, the results show that high-ESG disclosure REITs are larger, older, with lower leverage and performance. The pseudo R-square for the regression is 0.141 . In the post-match sample, all estimated coefficients are statistically insignificant, suggesting that there are no distinguishable trends in the ESG disclosure levels between the two groups. The pseudo R-square is 0.012 for the postmatch sample. The results suggest that the propensity score matching removes all observable differences among the sample other than the difference in the ESG disclosure levels.

In Panel B, none of the differences in firm characteristics between the treated group and the control group are statistically significant. These results suggest that the propensity score matching analysis removes all the other observable differences. Thus, the difference in the cost of debt, financial flexibility, corporate credit rating and market value of REITs between the two groups is likely due to their ESG disclosure levels.

Panel $\mathrm{C}$ reports the propensity score matching estimates. The matching variables include total assets, firm age, asset growth, NOI/TA, leverage, and cash stock. The results indicate that there are significant differences in the weighted average interest rate $(2.667 \%$ vs. $3.263 \%, t$-stat $=-6.01)$, the interest to debt ratio $(2.397 \%$ vs. $3.547 \%$, $t$-stat $=-6.55)$, the non-secured debt to total debt ratio $(0.739$ vs. $0.596, t$-stat $=3.95)$, the long-term debt to total debt ratio $(0.907$ vs. $0.862, t$-stat $=3.08)$, the corporate credit rating $(4.280$ vs. $3.879, t$-stat $=5.31)$, the market to book equity ratio $(1.254$ vs. $1.064, t$-stat $=2.91)$, and firm $Q(1116$ vs. $1.063, t$-stat $=1.87)$ between REITs with the highest ESG disclosure and those matched REITs.

The results show that the high-ESG-disclosure REITs have a lower cost of borrowing, more financial flexibility, better corporate credit rating and higher market

\footnotetext{
25 In Panels A and B, the results are based on the weighted average interest rate as the variable of interests. The results are quantitatively and qualitative similar when the ratio of interest to debt, the ratio of non-secured debt to total debt, the ratio of long-term debt to total debt ratio, corporate credit rating, market-to-book equity ratio, and firm $Q$ are used as the variable of interests. These results are not reported in the paper for brevity.
} 
value than the otherwise indistinguishable REITs. Taken together, the propensity score matching analysis provides supporting evidence to the main results.

\section{The Effect of 2019 ESG Disclosure on 2020 Market Valuation}

As the Covid-19 pandemic drastically changed the market environment of the stock markets including the REIT sector (e.g., Ling et al., 2020). We examine whether REIT ESG disclousre in 2019 plays a role in the market valuation in 2020. The results will provide additional robustness on the main results. Consistent with the media report, we find evidence that REITs continue to move forward with ESG disclosure during COVID-19 crisis $^{26}$. As shown in Panel A of Table 7, the average disclosure level of REITs increased from 3.08 to 3.35. We also find that firm value of REITs (measured by market to book ratio and firm $Q$ ) dropped significantly in 2020, compared to those in 2019. Specifically, the average market to book equity ratio (firm $Q$ ) of REITs decreased from 1.48 (1.21) to 1.30 (1.12).

Next, in Panel B of Table 7, we regress REIT firm value in 2020 on ESG disclusure level and firm characteristics in 2019. Overall, the results suggest that REITs with higher ESG disclosure levels before the pandemic have relatively higher firm value during the pandemic. These results using the coronavirus pandemic as a quasi-experiment suggest that investors do value higher levels of ESG disclosure by REITs.

\section{Institutional Ownership}

Previous finance literature documents that institutional investors are a major driving force behind a firm's ESG policies and practices (e.g., Dyck et al., 2019). We argue that, if REITs with a high level of institutional ownership tend to disclose more ESG information to the public, it would provide indirect but consistent evidence on the effects of ESG disclosure on cost of debt of REITs. That is, a higher level of ESG disclosure may help lower a REIT's cost of borrowing, because firms with greater institutional ownership are pushed harder for more ESG disclosure and the high ESG disclosure facilitates the firms to gain better access to the capital markets.

To examine the extent to which institutional investor ownership is related to REIT ESG disclosure, we regress ESG disclosure on a REIT's institutional ownership percentage and other key independent variables. The results are reported in Table 8. The estimated coefficient of total institutional ownership percentage is 1.677 and statistically significant at the $1 \%$ level, while the estimated coefficient of top 5 institutional ownership percentage is 1.940 and statistically significant at the $1 \%$ level $^{27}$. The results suggest that institutional investors seem to play a significant

\footnotetext{
26 See www.reit.com/news/reit-magazine/september-october-2020/reits-continue-focus-esg-during-covid19-crisis.

27 The rational using top 5 institutional ownership is that institutions with larger holdings usually do a better job of monitoring firms as those institutions normally have a lower cost of coordinating monitoring efforts (Hardin et al., 2017; Hartzell and Starks, 2003).
} 
Table 6 Propensity score matching results

\begin{tabular}{|c|c|c|c|c|}
\hline \multirow[b]{4}{*}{ Variables } & \multicolumn{4}{|c|}{ Dependent variable: High ESG disclosure } \\
\hline & \multicolumn{4}{|c|}{ Equals 1 if ESG public disclosure level is $\mathrm{A}$, and 0 otherwise } \\
\hline & \multicolumn{2}{|l|}{ Pre-match } & \multicolumn{2}{|l|}{ Post-match } \\
\hline & Coefficient & $z$-Statistic & Coefficient & $z$-Statistic \\
\hline \multicolumn{5}{|c|}{ Panel A. Pre-match propensity score regression and post-match diagnostic regression } \\
\hline Log firm size & $0.176^{* * * *}$ & 2.72 & 0.098 & 1.31 \\
\hline Log firm age & $0.454 * * *$ & 3.62 & 0.213 & 1.28 \\
\hline Firm growth & -0.008 & -1.18 & -0.007 & -0.81 \\
\hline Profitability & $-0.316^{* * *}$ & -7.39 & -0.081 & -1.34 \\
\hline Firm leverage & $-0.168^{*}$ & -1.65 & -0.121 & -1.00 \\
\hline Cash stock & -0.014 & -0.50 & 0.008 & 0.23 \\
\hline Constant & $-2.629 * *$ & -2.56 & -1.530 & -1.26 \\
\hline Number of observations & \multicolumn{2}{|l|}{643} & \multicolumn{2}{|l|}{330} \\
\hline Pseudo R-squared & \multicolumn{2}{|l|}{0.114} & \multicolumn{2}{|l|}{0.012} \\
\hline
\end{tabular}

Panel B Propensity score matching difference in firm characteristics

\begin{tabular}{lcccc}
\hline Variables & Treated $(\mathrm{N}=165)$ & Controls $(\mathrm{N}=165)$ & Difference & $t$-Statistic \\
\hline Log Firm Size & 15.053 & 14.877 & 0.176 & 1.01 \\
Log Firm Age & 2.467 & 2.390 & 0.077 & 0.96 \\
Firm Growth & 5.166 & 6.437 & -1.272 & -0.81 \\
Profitability & 4.059 & 4.256 & -0.196 & -0.85 \\
Firm Leverage & 0.900 & 1.004 & -0.104 & -0.95 \\
\hline
\end{tabular}

Panel C Propensity score matching estimator

\begin{tabular}{lllll}
\hline & $\begin{array}{l}\text { Treated } \\
\text { Variables }\end{array}$ & Mean & Controls & \\
Mean & Difference & $t$-Statistic \\
\hline Weighted average interest rate & 2.267 & 3.263 & -0.996 & -6.01 \\
Interest to-debt ratio & 2.397 & 3.547 & -1.149 & -6.55 \\
$\quad$ Non-secured debt to total debt & 0.739 & 0.596 & 0.036 & 3.95 \\
$\quad$ ratio & & & & 3.08 \\
Long-term debt to total debt & 0.907 & 0.862 & 0.014 & 5.31 \\
$\quad$ ratio & 4.280 & 3.879 & 0.402 & 2.91 \\
Corporate credit rating & 1.254 & 1.064 & 0.190 & 1.85 \\
Market to book equity ratio & 1.116 & 1.063 & 0.053 & \\
Firm $Q$ & & & & \\
\hline
\end{tabular}

This table reports the propensity score matching results. Panel A reports the parameter estimates from the logit model (i.e., pre-match propensity score regression and the post-match diagnostic regression) used to estimate the propensity scores for the weighted average interest rate. The dependent variable is an indicator variable set to one if REITs are with high ESG public disclosure (i.e., ESG Public Disclosure Level is A (57-70 points), and zero otherwise. The control variables include firm size, firm age, assets growth, profitability, leverage, and cash stock. Panel B reports the univariate comparisons of firm characteristics between the treated group and the control group and the corresponding t-statistics. The treated group consists of REITs with high ESG public disclosure level. In Panels A and B, the results are based on the weighted average interest rate as the variable of interests. Panel $\mathrm{C}$ reports estimates of the aver- 
Table 6 (continued)

age treatment effects. The dependent variable is the weighted average interest rate, the ratio of interest to debt, the ratio of non-secured debt to total debt, the ratio of long-term debt to total debt, corporate credit rating, market to book equity ratio, and firm $Q$, respectively. The matching variables include firm size, firm age, assets growth, profitability, leverage, and cash stock. Significance at the $1 \%, 5 \%$, or $10 \%$ level is presented as 3, 2, or 1 asterisk respectively

Table 7 The effect of 2019 ESG disclosure on 2020 market valuation

Panel A. ESG disclosure level and market valuation of REITs in 2019 and 2020

\begin{tabular}{|c|c|c|c|c|c|c|}
\hline & & 2019 & 2020 & $\begin{array}{l}\text { 2019-2020 } \\
\text { Spread }\end{array}$ & $t$-test & $\begin{array}{l}\text { rank-sum } \\
\text { test }\end{array}$ \\
\hline \multirow[t]{2}{*}{ ESG disclosure Level } & Mean & 3.084 & 3.350 & -0.266 & -2.220 & \\
\hline & Median & 3.000 & 4.000 & 1.000 & & -2.155 \\
\hline \multirow[t]{2}{*}{ Market to book equity ratio } & Mean & 1.483 & 1.303 & 0.180 & 2.356 & \\
\hline & Median & 1.239 & 1.042 & 0.197 & & 4.138 \\
\hline \multirow[t]{2}{*}{ Firm $Q$} & Mean & 1.214 & 1.122 & 0.092 & 3.035 & \\
\hline & Median & 1.144 & 1.075 & 0.011 & & 4.153 \\
\hline \multirow{2}{*}{$\begin{array}{l}\text { Panel B: Regression results } \\
\text { Variables }\end{array}$} & \multicolumn{3}{|c|}{ Market to book equity ratio } & \multicolumn{3}{|c|}{ Firm $Q$} \\
\hline & \multicolumn{2}{|l|}{ Coef } & $t$-Stat & \multicolumn{2}{|l|}{ Coef } & $t$-Stat \\
\hline ESG disclosure level—B & \multicolumn{2}{|l|}{$-0.234 * *$} & -2.03 & \multicolumn{2}{|c|}{$-0.122 * * *$} & -2.65 \\
\hline ESG disclosure level-C & \multicolumn{2}{|l|}{$-0.246^{*}$} & -1.83 & \multicolumn{2}{|c|}{$-0.114 * *$} & -2.03 \\
\hline ESG disclosure level—D & \multicolumn{2}{|l|}{$-0.313^{*}$} & -1.76 & \multicolumn{2}{|c|}{$-0.145 * *$} & -2.17 \\
\hline ESG disclosure level-E & \multicolumn{2}{|l|}{$-0.369 * * *$} & -2.83 & \multicolumn{2}{|c|}{$-0.155 * * *$} & -2.93 \\
\hline Log firm size & \multicolumn{2}{|l|}{-0.017} & -0.53 & \multicolumn{2}{|c|}{$-0.029 * *$} & -2.21 \\
\hline Log firm age & \multicolumn{2}{|l|}{0.050} & 0.68 & \multicolumn{2}{|c|}{0.023} & 0.85 \\
\hline Firm growth & \multicolumn{2}{|l|}{$0.011 * * *$} & 3.82 & \multicolumn{2}{|c|}{$0.005 * * *$} & 4.12 \\
\hline Profitability & \multicolumn{2}{|l|}{$0.233 * * *$} & 5.28 & \multicolumn{2}{|c|}{$0.089 * * *$} & 5.33 \\
\hline Firm leverage & \multicolumn{2}{|l|}{$0.300 * * *$} & 3.63 & \multicolumn{2}{|c|}{0.003} & 0.14 \\
\hline Cash stock & \multicolumn{2}{|l|}{0.034} & 1.49 & \multicolumn{2}{|c|}{0.006} & 1.03 \\
\hline Constant & \multicolumn{2}{|l|}{-0.616} & -0.79 & \multicolumn{2}{|c|}{$0.865^{* * *}$} & 2.96 \\
\hline Observations & \multicolumn{3}{|l|}{295} & \multicolumn{2}{|l|}{298} & \\
\hline$R$-squared & \multicolumn{3}{|l|}{0.544} & \multicolumn{2}{|c|}{0.528} & \\
\hline Property type FE & YES & & & YES & & \\
\hline Global region FE & YES & & & YES & & \\
\hline
\end{tabular}

This table reports the effect of 2019 ESG disclosure on 2020 market valuation of REITs. Panel A presents the statistics of ESG disclosure level and market valuation of REITs in 2019 and 2020. Mean, median, $t$-statistics from the $t$-test and the $z$-statistics from the Wilcoxon rank-sum test are reported. Panel B presents the results of regressing the 2020 market valuation (i.e., market to book equity ratio and firm $Q$ ) measures of REITs on 2019 ESG disclosure level. ESG disclosure level is also a categorical variable [i.e., Disclosure Level $=5$ if ESG Public Disclosure Level is A (57-70 points), Disclosure Level = 4 if ESG Public Disclosure Level is B (43-56 points), Disclosure Level = 3 if ESG Public Disclosure Level is C (27-42 points), Disclosure Level = 2 if ESG Public Disclosure Level is D (15-28points), Disclosure Level $=1$ if ESG Public Disclosure Level is E (0-14 points)]. Standard errors are computing using HC3 robust standard errors. $t$-statistics are reported in brackets. The coefficients of property types and global regions are suppressed from reporting. Significance at the $1 \%, 5 \%$, or $10 \%$ level is shown with 3,2 , or 1 asterisk, respectively 
Table 8 Institutional ownership and ESG disclosure

\begin{tabular}{lllll}
\hline Variables & $(1)$ & $(2)$ & $(3)$ & $(4)$ \\
\hline Total institutional ownership percentage & $1.677^{* * *}$ & 6.06 & & \\
Top 5 institutional ownership percentage & & & $1.940^{* * *}$ & 3.53 \\
Log firm size & $0.367^{* * *}$ & 6.85 & $0.366^{* * *}$ & 6.42 \\
Log firm age & $0.260^{* * *}$ & 2.84 & $0.254^{* * *}$ & 2.72 \\
Firm growth & $-0.012^{* * *}$ & -3.43 & $-0.009^{* *}$ & -2.53 \\
Profitability & $-0.072^{* *}$ & -2.54 & $-0.059^{* *}$ & -2.05 \\
Firm leverage & 0.066 & 1.40 & 0.035 & 0.78 \\
Cash Stock & -0.020 & -0.98 & -0.019 & -0.89 \\
Constant & $-5.592^{* * *}$ & -5.84 & $-5.133^{* * *}$ & -5.03 \\
Observations & 643 & & 636 & \\
$R$-squared & 0.411 & & 0.369 & \\
Property type FE & YES & & YES & \\
Global region FE & YES & & YES & \\
\hline
\end{tabular}

This table reports the regression results of ESG disclosure level on institutional ownership percentage (total institutional ownership percentage and top 5 institutional ownership percentage). ESG disclosure level is a categorical variable [i.e., Disclosure Level $=5$ if ESG Public Disclosure Level is A (57-70 points), Disclosure Level $=4$ if ESG Public Disclosure Level is B (43-56 points), Disclosure Level $=3$ if ESG Public Disclosure Level is C (27-42 points), Disclosure Level = 2 if ESG Public Disclosure Level is D (15-28points), Disclosure Level $=1$ if ESG Public Disclosure Level is E (0-14 points)]. Standard errors are clustered at the firm level and are heteroscedasticity-robust. Public Disclosure Level A is set as the base level and omitted in the regression. $t$-statistics are reported in brackets. The coefficients of property types and global regions are suppressed from reporting. Significance at the $1 \%, 5 \%$, or $10 \%$ level is shown with 3,2 , or 1 asterisk, respectively

role in shaping REIT ESG disclosure practices, implying that the push from institutional investors for more ESG disclosure may help lower cost of debt for REITs with higher ESG disclosure levels.

\section{REITs with and Without ESG Disclosure Rating}

Lastly, we examine the differences between REITs with and without ESG disclosure ratings. In 2019 and 2020, the majority of REITs (706 out of 964 firm years) recorded in the S\&P Global database provide their ESG public disclosure information, while some of them (258 out of 964 firm years) are recorded without such information. To examine the differentials on cost of debt, financial flexibility and market value between REITs with and without ESG disclosure ratings, we construct an ESG disclosure dummy variable, which is equal to 1 if a REIT is with an ESG Disclosure Level, and 0 otherwise, and then regress REIT financing and market value measures on the ESG Disclosure dummy.

Table 9 reports the regression results. Overall, REITs with ESG disclosure ratings display lower cost of debt, more financial flexibility and higher market value. specifically, the estimated coefficients of the ESG disclosure dummy are -0.658 and 


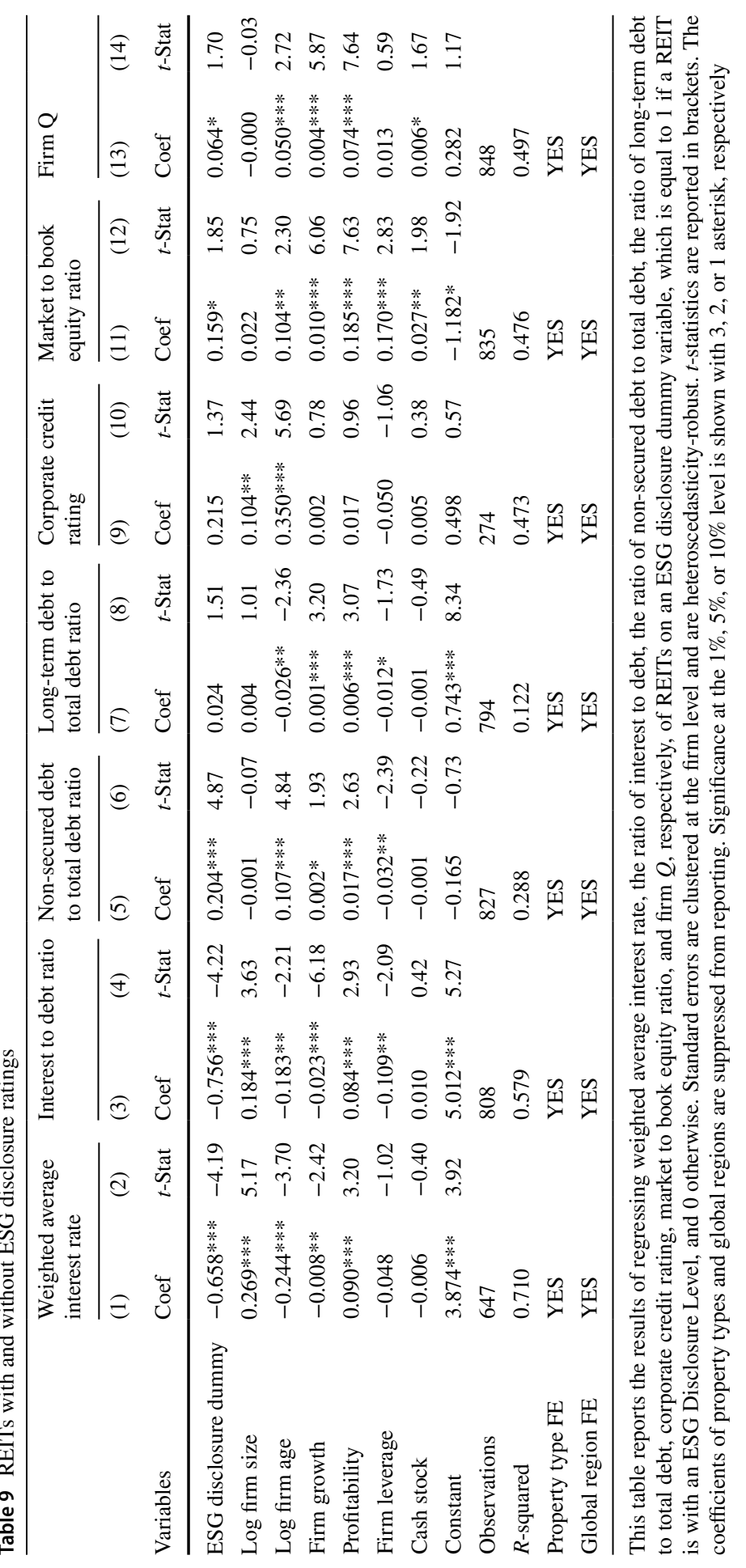


-0.756 when the dependent variables are weighted average interest rate and interest to debt ratio, respectively. Both display statistical significance at the $1 \%$ level. The estimated coefficients are $0.204(t$-statistic $=4.87)$ and $0.024(t$-statistic $=1.51)$ when the dependent variables are non-secured debt to total debt ratio and long-term debt to total debt ratio, respectively. Regarding market value, the estimated coefficients are 0.159 and 0.064 with statistical significance at the $10 \%$ level. The results on REITs with and without ESG disclosure ratings also provide some evidence pertaining to the effects of ESG disclosure on REITs' cost of debt, financial flexibility and market value.

\section{Conclusion}

Environmental, Social, and Governance (ESG) are of great importance to REITs due to the nature of the real estate business, growing risks from climate changes, and the increasing demand for sustainability and social responsibility from REIT stakeholders. To integrate ESG factors into business decisions, REIT stakeholders must accurately capture ESG related information. However, recent research shows that substantial disagreement exists across ESG data providers and there is a lack of an effective, standardized ESG reporting framework, which may mislead investors and lenders in their decision-making. Thus, in recent years ESG disclosure has received significant attention among REIT stakeholders. In this study, we examine how ESG disclosure is related to REIT debt financing and firm value, using a recently available ESG disclosure dataset for REITs around the world.

We find strong evidence that firm-level cost of debt of REITS is negatively associated with their ESG disclosure level, controlling for key firm characteristics. Also, REITs with higher ESG disclosure levels retain more financial flexibility and have higher market value. When using the Covid-19 pandemic as a quasi-experimental setting, we find evidence that REITs with higher ESG disclosure levels before the pandemic have higher firm value during the pandemic. To address the potential omitted variable problem, a propensity score matching model is used, and the results are consistent. Additional analyses show that REITs with higher institutional ownership tend to have higher ESG disclosure levels and that there exist substantial differences in the financing and market value between REITs with and without ESG disclosure ratings in the sample.

These findings show the importance of ESG disclosure to REITs and have implications for REIT managers and other stakeholders. It is essential for REITs to actively disclose ESG information as there is significant relationships between ESG disclosure and REIT debt financing and firm value. In other words, REITs that do not effectively disclose ESG information may face unfavorable conditions in the capital markets, compared to their industry peers. Meanwhile, given that ESG disclosure for REITs are still at relatively early state and many REITs and stakeholders have struggled to identify what ESG criteria to focus, the results suggest that the ESG reporting framework developed by GRESB appears to be effective for the global real estate industry, and the ESG disclosure data can be used by REIT stakeholders to analyze ESG disclosure quality among global REITs. 
The present study extends the REIT literature on ESG by providing some initial evidence on ESG disclosure level for REITs around the world. Moreover, the results in this paper based on a single, homogeneous industry provide more reliable evidence when compared with those obtained from different industries, which arguably have large variations in their ESG disclosure levels and capital structure across the industries. In this sense, the study also adds to the broader ESG literature. Taken together, this paper suggests that greater ESG disclosure can have a positive impact on REIT debt financing and firm value, and the standardized ESG reporting framework provided by GRESB appears to effective for the global REIT industry.

To our knowledge, this is the first study to investigate REIT ESG disclosure and its potential impacts on REIT financing and firm value, using the recently available data. While the evidence on the positive relations between ESG disclosure and cost of debt, financial flexibility and firm value of REITs seems to be clear and consistent, we recognized that our empirical analysis has some limitations due to the data availability. Nevertheless, we believe that future research regarding the impacts of ESG disclosure on REIT capital structure, operations and performance should be fruitful.

\section{Declarations}

Conflict of interest The author declared that there is no conflict of interest.

\section{References}

Aivazian, V. A., Qiu, J., \& Rahaman, M. M. (2015). Bank loan contracting and corporate diversification: Does organizational structure matter to lenders? Journal of Financial Intermediation, 24(2), 252-282.

Allen, L., \& Letdin, M. (2020). The cost of debt for REITs: The mortgage puzzle. Journal of Real Estate Research. Forthcoming.

Allen, M. T., Madura, J., \& Springer, T. M. (2000). REIT characteristics and the sensitivity of REIT returns. Journal of Real Estate Finance and Economics, 21(2), 141-152.

Ambrose, B. W., Highfield, M. J., \& Linneman, P. D. (2005). Real estate and economies of scale: The case of REITs. Real Estate Economics, 33(2), 323-350.

An, H., Cook, D. O., \& Zumpano, L. V. (2011). Corporate transparency and firm growth: Evidence from real estate investment trusts. Real Estate Economics, 39(3), 429-454.

An, X., \& Pivo, G. (2020). Green buildings in commercial mortgage-backed securities: The effects of LEED and energy star certification on default risk and loan terms. Real Estate Economics, 48(1), $7-42$.

Azar, J., Duro, M., Kadach, I., \& Ormazabal, G. (2021). The Big Three and corporate carbon emissions around the world. Journal of Financial Economics Forthcoming. https://doi.org/10.1016/j.jfineco. 2021.05.007

Beatty, A., Ramesh, K., \& Weber, J. (2002). The importance of accounting changes in debt contracts: The cost of flexibility in covenant calculations. Journal of Accounting and Economics, 33, 205-227.

Beracha, E., Feng, Z., \& Hardin, W. (2019). REIT operational efficiency and shareholder value. Journal of Real Estate Research, 414, 513-553.

Brounen, D., Marcato, G., \& Op't Veld, H. (2021). Pricing ESG equity ratings and underlying data in listed real estate securities. Sustainability Forthcoming. https://doi.org/10.3390/su13042037

Buchanan, B., Cao, C. X., \& Chen, C. (2018). Corporate social responsibility, firm value, and influential institutional ownership. Journal of Corporate Finance., 52, 73-95. 
Chiang, K., Wachtel, G., \& Zhou, X. (2019). Corporate social responsibility and growth opportunity: The case of real estate investment trusts. Journal of Business Ethics, 155(2), 463-478.

Christensen, D., Serafeim, G., \& Sikochi, A. (2021). Why is Corporate Virtue in the Eye of The Beholder? The Case of ESG Ratings. The Accounting Review, Forthcoming. Doi: https://doi.org/10.2308/ TAR-2019-0506

Cloutier, E. (2020). The new norm: ESG as a material risk and opportunity for real estate. Real Estate Issues, 44(16), 1-7.

Cowton, C. J., \& Thompson, P. (2000). Do codes make a difference? The case of bank lending and the environment. Journal of Business Ethics, 24(2), 165-178.

Deng, S. E., Elyasiani, E., \& Mao, C. X. (2007). Diversification and the cost of debt of bank holding companies. Journal of Banking \& Finance, 31(8), 2453-2473.

Deng, Y., Devos, E., Rahman, S., \& Tsang, D. (2016). The role of debt covenants in the investment grade bond market-the REIT experiment. Journal of Real Estate Finance and Economics, 52(4), 428-448.

Derrien, F., Kecskés, A., \& Mansi, S. (2016). Information asymmetry, the cost of debt, and credit events: Evidence from quasi-random analyst disappearances. Journal of Corporate Finance, 39, 295-311.

Devos, E., Devos, E., Ong, S. E., \& Spieler, A. C. (2019). Information asymmetry and REIT capital market access. Journal of Real Estate Finance and Economics, 59(1), 90-110.

Dhaliwal, D., Li, Z., Tsang, A., \& Yang, Y. (2011). Voluntary nonfinancial disclosure and the cost of equity capital: The initiation of corporate social responsibility reporting. The Accounting Review, 86(1), 59-100.

Diamond, D. W. (1985). Optimal release of information by firms. Journal of Finance, 40, 1071-1094.

Diamond, D., \& Verrecchia, R. (1991). Disclosure, liquidity, and the cost of capital. Journal of Finance, 46(4), 1325-1359.

Dimson, E., Karakaş, O., \& Li, X. (2015). Active ownership. Review of Financial Studies, 28(12), 3225-3268.

Dogan, Y. Y., Ghosh, C., \& Petrova, M. (2019). On the determinants of REIT capital structure: Evidence from around the world. Journal of Real Estate Finance and Economics, 59, 295-328.

Dyck, A., Lins, K. V., Roth, L., \& Wagner, H. F. (2019). Do institutional investors drive corporate social responsibility? International evidence. Journal of Financial Economics, 131, 693-714.

Eichholtz, P., Holtermans, R., Kok, N., \& Yönder, E. (2019). Environmental performance and the cost of debt: Evidence from commercial mortgages and REIT bonds. Journal of Banking \& Finance, 102, 19-32.

Eichholtz, P., Kok, N., \& Quigley, J. M. (2013). The economics of green building. Review of Economics and Statistics, 95(1), 50-63.

Faulkender, M., \& Wang, R. (2006). Corporate Financial Policy and the Value of Cash. Journal of Finance, 61(4), 1957-1990.

Feng, Z., Ghosh, C., \& Sirmans, C. F. (2007). On the capital structure of real estate investment trusts. Journal of Real Estate Finance and Economics, 34(1), 81-105.

Flammer, C. (2021). Corporate green bonds. Journal of Financial Economics. Forthcoming.

Flammer, C. (2015). Does corporate social responsibility lead to superior financial performance? A regression discontinuity approach. Management Science, 61(11), 2549-2568.

Fuerst, F., \& McAllister, P. (2011). Green noise or green value? Measuring the effects of environmental certification on office values. Real Estate Economics, 39(1), 45-69.

Gelb, D. S., \& Strawser, J. A. (2001). Corporate social responsibility and financial disclosures: An alternative explanation for increased disclosure. Journal of Business Ethics, 33(1), 1-13.

Giacomini, E., Ling, D. C., \& Naranjo, A. (2017). REIT leverage and return performance: Keep your eye on the target. Real Estate Economics, 45(4), 930-978.

Gillan, S., Koch, A., \& Starks, L. (2021). Firms and social responsibility: A review of ESG and CSR research in corporate finance. Journal of Corporate Finance. https://doi.org/10.2308/TAR-2019-0506

Goss, A., \& Roberts, G. S. (2011). The impact of corporate social responsibility on the cost of bank loans. Journal of Banking and Finance., 35(7), 1794-1810.

Hann, R. N., Ogneva, M., \& Ozbas, O. (2013). Corporate diversification and the cost of capital. Journal of Finance, 68(5), 1961-1999.

Hardin, W. G., Nagel, G. L., Roskelley, K. D., \& Seagraves, P. A. (2017). Institutional monitoring, motivated investors, and firm performance. Journal of Real Estate Research, 39(3), 401-440.

Hartzell, J. C., \& Starks, L. T. (2003). Institutional investors and executive compensation. Journal of Finance, 58(6), 2351-2374.

Hoepner, A., Oikonomou, I, Sautner, Z., Starks, L, \& Zhou, X. (2021). ESG Shareholder Engagement and Downside Risk. European Corporate Governance Institute - Finance Working Paper No. 671.

Hudson, J. (2019). The Rise of ESG in Real Estate. State Street Corporation. 
Ioannou, I., \& Serafeim, G. (2017). The consequences of mandatory corporate sustainability reporting. Harvard Business School research working paper, (11-100).

Jacobs, B. W., Singhal, V. R., \& Subramanian, R. (2010). An empirical investigation of environmental performance and the market value of the firm. Journal of Operations Management, 28(5), 430-441.

Jaffee, D., \& Russell, T. (1976). Imperfect Information, Uncertainty, and Credit Rationing. Quarterly Journal of Economics, 90, 651-666.

Jensen, M.C., \& Meckling, W.H. (1979). Theory of the Firm: Managerial Behavior, Agency Costs, and Ownership Structure. In Economics social institutions (pp. 163-231). Springer, Dordrecht.

Kim, E. H., \& Lyon, T. P. (2015). Greenwash vs. brownwash: Exaggeration and undue modesty in corporate sustainability disclosure. Organization Science, 26(3), 705-723.

Kim, D., Lim, D., \& Wiley, J. A. (2021). Narrative investment-risk disclosure \& REIT investment. Journal of Real Estate Finance and Economics. Forthcoming.

Kisgen, D. J. (2006). Credit ratings and capital structure. Journal of Finance, 61(3), 1035-1072.

Lamont, O. A., \& Polk, C. (2002). Does diversification destroy value? Evidence from the industry shocks. Journal of Financial Economics, 63(1), 51-77.

Letdin, M., Sirmans, C. S., Sirmans, G. S., \& Zietz, E. N. (2019). Explaining REIT returns. Journal of Real Estate Literature, 27(1), 1-25.

Ling, D. C., Wang, C., and Zhou, T. (2020). A first look at the impact of COVID19 on commercial real estate prices: Asset level evidence. Review of Asset Pricing Studies. Forthcoming.

Matsumura, E., Prakash, R., \& Vera-Muñoz, S. (2014). Firm-Value effects of carbon emissions and carbon disclosures. The Accounting Review, 89(2), 695-724.

Morri, G., \& Parri, E. (2017). US REITs capital structure determinants and financial economic crisis effects. Journal of Property Investment \& Finance., 35(6), 556-574.

Myers, S., \& Majluf, N. (1984). Corporate financing and investment decisions when firms have information that investors do not have. Journal of Financial Economics, 13(2), 187-221.

Newell, G., \& Lee, C. L. (2012). Influence of the corporate social responsibility factors and financial factors on REIT performance in Australia. Journal of Property Investment \& Finance., 30(4), 389-403.

Ott, S. H., Riddiough, T. J., \& Yi, H. C. (2005). Finance, investment and investment performance: Evidence from the REIT sector. Real Estate Economics, 33(1), 203-235.

Pastor, L., Stambaugh, R., \& Taylor, L. (2021). Sustainable investing in equilibrium. Journal of Financial Economics. Forthcoming. https://doi.org/10.1016/j.jfineco.2020.12.011.

Pedersen, L. Fitzgibbons, S., \& Pomorski L. (2021). Responsible investing: The ESG-efficient frontier. Journal of Financial Economics. Forthcoming.https://doi.org/10.1016/j.jineco.2020.11.001.

Pivo, G., \& Fisher, J. (2010). Income, value, and returns in socially responsible office properties. Journal of Real Estate Research, 32(3), 243-270.

Plumlee, M., Brown, D., Hayes, R. M., \& Marshall, R. S. (2015). Voluntary environmental disclosure quality and firm value: Further evidence. Journal of Accounting and Public Policy, 34(4), 336-361.

Qian, J., \& Strahan, P. E. (2007). How laws and institutions shape financial contracts: The case of bank loans. Journal of Finance, 62(6), 2803-2834.

Fitch Ratings (2020). ESG Bites into Banks' Lending to Corporates. https://www.fitchratings.com/research/ banks/esg-bites-into-banks-lending-to-corporates-07-01-2020.

Reichardt, A., Fuerst, F., Rottke, N., \& Zietz, J. (2012). Sustainable building certification and the rent premium: A panel data approach. Journal of Real Estate Research, 34(1), 99-126.

Riddiough, T., \& Steiner, E. (2020). Financial Flexibility and Manager-Shareholder Conflict: Evidence from REITs. Real Estate Economics, 48(1), 200-239.

Servaes, H., \& Tamayo, A. (2013). The impact of corporate social responsibility on firm value: The role of customer awareness. Management Science., 59(5), 1045-1061.

Stiglitz, J. E., \& Weiss, A. (1981). Credit rationing in markets with imperfect information. American Economic Review, 71(3), 393-410.

Wiley, J. A., Benefield, J. D., \& Johnson, K. H. (2010). Green design and the market for commercial office space. Journal of Real Estate Finance and Economics, 41(2), 228-243.

Zerbib, O. D. (2019). The effect of pro-environmental preferences on bond prices: Evidence from green bonds. Journal of Banking and Finance., 98, 39-60.

Publisher's Note Springer Nature remains neutral with regard to jurisdictional claims in published maps and institutional affiliations. 